\title{
Role of H1 Linker Histones in Mammalian Development and Stem Cell Differentiation
}

\author{
Chenyi Pan ${ }^{1,2}$, Yuhong Fan ${ }^{1,2, \#}$
}

${ }^{1}$ School of Biology, Georgia Institute of Technology, Atlanta, GA 30332, USA;

${ }^{2}$ The Petit Institute for Bioengineering and Bioscience, Georgia Institute of Technology, Atlanta, GA 30332, USA;

\# Corresponding author:

Yuhong Fan, PhD

School of Biology and the Petit Institute for Bioengineering and Bioscience

Georgia Institute of Technology

IBB 2313, 315 Ferst Drive, Atlanta, GA 30332-0363, USA

Email: Yuhong.fan@biology.gatech.edu;

Phone: 404-385-1312; Fax: 404-894-0519 


\begin{abstract}
H1 linker histones are key chromatin architectural proteins facilitating the formation of higher order chromatin structures. The $\mathrm{H} 1$ family constitutes the most heterogeneous group of histone proteins, with eleven non-allelic $\mathrm{H} 1$ variants in mammals. $\mathrm{H} 1$ variants differ in their biochemical properties and exhibit significant sequence divergence from one another, yet most of them are highly conserved during evolution from mouse to human. H1 variants are differentially regulated during development and their cellular compositions undergo dramatic changes in embryogenesis, gametogenesis, tissue maturation and cellular differentiation. As a group, H1 histones are essential for mouse development and proper stem cell differentiation. Here we summarize our current knowledge on the expression and functions of $\mathrm{H} 1$ variants in mammalian development and stem cell differentiation. Their diversity, sequence conservation, complex expression and distinct functions suggest that H1s mediate chromatin reprogramming and contribute to the large variations and complexity of chromatin structure and gene expression in the mammalian genome.
\end{abstract}




\section{Key words}

Linker histones, H1 variants, mammalian development, stem cell differentiation, chromatin, epigenetic gene regulation 


\section{Overview: Histone $\mathrm{H} 1$ and its variants in mammals}

The DNA of all eukaryotic nuclei is packaged into chromatin by association with histone proteins. The basic repeating unit of chromatin is the nucleosome core particle, which consists of an octamer of four core histones (H2A, H2B, H3 and H4) wrapped by 147 bp of DNA [1, 2]. Linker histone $\mathrm{H} 1$ binds to nucleosome core particles and the linker DNA between nucleosomes to facilitate the folding of the "beads-on-a-string" extended chromatin fiber into higher order chromatin structures, the 30-nm fiber [3-6]. For gene transcription to occur, the chromatin template plays a dynamic role. Nucleosome core particles and posttranslational modifications of core histones, such as acetylation, methylation, ubiquitination, phosphorylation and sumoylation, have been shown to play critical roles in gene activation and repression. Much less is known about the role of linker histone $\mathrm{H} 1$ and its variants. Here we focus our discussion on recent studies about the function of mammalian $\mathrm{H} 1 \mathrm{~s}$ in development and stem cell differentiation.

The H1 histone family is the most divergent and heterogeneous group of histones among the evolutionarily conserved histone protein families. There are multiple nonallelic linker histone variants present in higher organisms which provide additional levels of regulation on chromatin structure and function [7, 8]. In mammals, $11 \mathrm{H} 1$ variants have been identified, including seven somatic $\mathrm{H} 1 \mathrm{~s}\left(\mathrm{H}^{0}{ }^{0}, \mathrm{H} 1 \mathrm{a}, \mathrm{H} 1 \mathrm{~b}, \mathrm{H} 1 \mathrm{c}, \mathrm{H} 1 \mathrm{~d}, \mathrm{H} 1 \mathrm{e}\right.$ and $\left.\mathrm{H} 1 \mathrm{x}\right)$ and four germ cellspecific H1s (H1t, H1T2, H1LS1 and H1oo) (Table 1). Among the multiple nomenclature systems for mammalian somatic $\mathrm{H} 1$ variants, the alphabetic nomenclature $\left(\mathrm{H} 1 \mathrm{a}-\mathrm{e}, \mathrm{H} 1^{0}\right.$ and $\left.\mathrm{H} 1 \mathrm{x}\right)$ and the alternative numeric system (H1.1-1.5, H1.0 and H1.x) are most commonly used [8-12]. Table 1 summarizes their nomenclature as well as H1 variants' distinct expression and genomic localization patterns. 
The expression of $\mathrm{H} 1$ variants is differentially regulated during mammalian development and cellular differentiation [13-19]. H1a through H1e are the main types of H1 ubiquitously expressed in somatic cells, yet their expression is tightly regulated with distinct levels in different tissues and cell types $[14,15,20,21] . \mathrm{H} 1^{0}$ is expressed mainly in differentiated and nondividing cells [22], whereas the least characterized H1x appears to exhibit a G1 phasedependent nucleolar accumulation in cultured human cell lines [23]. H1oo and H1t are germ cell-specific H1s with expression in oocytes and testis, respectively [24, 25]. H1T2 and H1LS1 are two H1t-related H1s specifically expressed in spermatids [26-30].

All of the mammalian $\mathrm{H} 1$ genes are transcribed by RNA Pol II. The genes of major somatic $\mathrm{H} 1$ variants (H1a, H1b, H1c, H1d and H1e) and H1t are intronless and transcribed in S phase of cell cycle in a DNA replication-dependent manner (Table 1). Their mRNAs have characteristics of DNA replication-coupled histone mRNAs, lacking a poly(A) tail but terminated by a conserved 3' stem-loop structure. This stem-loop hairpin is bound by the histone RNA hairpin-binding protein or stem-loop binding protein (SLBP) which is required for histone pre-mRNA processing and enhances translation [31-35]. The transcription of these six $\mathrm{H} 1$ genes involves typical cell cycle regulation of histone genes: transcription initiation, 3'end processing and mRNA stability. Interestingly, $H I c$ gene also produces a polyadenylated form of mRNA besides the 3' stem-loop form mRNA, allowing for independent regulation of expression in dividing and nondividing cells [36]. These six H1 genes (H1a-e and H1t) are linked and clustered together with core histone genes on mouse chromosome 13 and the orthologous human chromosome $6[14,21,37-40]$. This genomic organization is conserved from mouse to human. The other five $\mathrm{H} 1$ genes, $\mathrm{HI}^{\circ}, \mathrm{Hlx}$, Hloo, HIt2 and Hils1, however, are expressed in a DNA replication-independent manner, with mRNAs polyadenylated and lacking the 3' stem-loop 
structure. In addition, they are not clustered with core histones but scattered in the mammalian genomes (Table 1).

All metazoan H1s share the same tripartite domain structure that includes a short, flexible $\mathrm{N}$-terminal tail domain (NTD), a central globular domain (GD) with a winged-helix motif and a long, lysine-rich C-terminal tail domain (CTD) [41-43]. The H1 globular domain is highly conserved, while the $\mathrm{N}$ - and $\mathrm{C}$-terminal regions of $\mathrm{H} 1$ variants contain more sequence divergence. Comparison of the sequences of mouse and human $\mathrm{H} 1$ genes reveals that each mouse $\mathrm{H} 1$ variant gene is more similar to its human ortholog than to other mouse $\mathrm{H} 1$ variant genes (Fig. 1, Table 2) [44]. Table 2 summarizes the sequence comparisons among all H1 variants in mice and humans. Mouse and human $\mathrm{H}^{0}(\mathrm{H} 1.0)$ are particularly conserved with 94.8\% of homology, whereas they have diverged significantly from other H1 variants with homology less than 45\% (Table 2) [44]. On the other hand, H1b (H1.5), H1c (H1.2), H1d (H1.3) and H1e (H1.4) are not only highly conserved from mouse to human with over $85 \%$ sequence identity, but also share most similarities with each other, with $76-86 \%$ sequence identity. Their sequence similarity suggests that $\mathrm{H} 1 \mathrm{~b}, \mathrm{H} 1 \mathrm{c}, \mathrm{H} 1 \mathrm{~d}$ and $\mathrm{H} 1 \mathrm{e}$ may be more functionally related to each other than to other H1s. Among the 7 somatic H1s, H1x is the least conserved and the most divergent, with $70.9 \%$ identity between mouse and human $\mathrm{H} 1 \mathrm{x}$ and less than $37 \%$ similarities with other somatic H1s. H1x also contains a lower content of basic amino acid residues [45, 46]. Germ cell-specific H1 variants are generally less conserved and more divergent than somatic H1s (Table 2). Mouse H1t shares a moderate identity of $61 \%$ with human H1t and 26-55\% with somatic H1s, whereas other germ cell-specific H1s (H1oo, H1T2 and HILS1) have only 10-27\% sequence identity with other $\mathrm{H} 1$ variants. The sequence conservation of the individual H1 
variants suggests that $\mathrm{H} 1$ variants may have distinct roles in chromatin function and gene regulation in various cellular and developmental processes.

Consistent with the sequence heterogeneity of $\mathrm{H} 1$ variants, cumulative evidence suggests that $\mathrm{H} 1$ variants differ in their biochemical properties, affinities for chromatin, capabilities in chromatin compaction and binding partners [42, 47-62]. The globular and C-terminal domains are required for high-affinity binding of $\mathrm{H} 1$ to chromatin [42, 47-49]. The globular domain is suggested to bind to nucleosomes at the dyad and the linker DNA with symmetric or asymmetric models [42, 63-67], whereas the CTD is likely to bind to the linker DNA non-specifically. The globular domain of $\mathrm{H} 1$ variants may bind to nucleosomes in distinctive structural modes, leading to varied higher order structures [67]. Atomic force microscopy, in vitro biochemical assays and fluorescence recovery after photobleaching (FRAP) studies have suggested that H1b, H1d and $\mathrm{H} 1 \mathrm{e}$, the somatic H1s with longer C-terminal tails, display higher affinity for chromatin than H1a, $\mathrm{H} 1 \mathrm{c}$ and $\mathrm{H}^{0}$, the somatic H1s with shorter C-terminal tails [51-53]. H1b and H1d are sometimes categorized into the intermediate group of chromatin binding affinity, so is $\mathrm{H} 1^{0}$, the most lysine-rich H1 with a short C-terminal tail [51-53]. The CTD appears to be the key determinant for the chromatin binding affinity of somatic H1s $[48,53]$. The function of CTD in condensing chromatin is related to its length, the density of basic residues, the number of S/TPXK sites and its specific amino acid composition, as well as the intrinsic protein disorder in the CTD [53, 68]. The N-terminal tail appears to be dispensable for chromatin binding, nevertheless, its deletion or swapping between different $\mathrm{H} 1$ variants alters the binding affinity of the respective $\mathrm{H} 1$ variant for chromatin $[47,48,50]$. Not surprisingly, different $\mathrm{H} 1$ variants also display differential in vivo binding dynamics in oocytes and during ES cell nuclear transfer [69]. The binding of $\mathrm{H} 1$ to chromatin is also regulated by post-translational modifications $[54,55,70]$ 
and histone chaperones [71, 72]. In addition to binding to DNA and nucleosomes, H1 variants interact with a variety of cellular proteins, which contributes to their diverse functions in various cellular processes [58-62].

Germ cell-specific H1 variants differ dramatically from somatic H1s in amino acid sequences and biochemical properties. H1t exhibits lower binding affinity for DNA and condenses chromatin to a lesser extent than somatic H1s [73-75], which may be attributed to the absence of the S/TPXK motifs, the sites for DNA binding and phosphorylation in CTD [76-78], and the single amino acid substitution of lysine observed in somatic H1s by glutamine in the H1t globular domain [79]. H1T2 is distinctive from H1t in that it is highly enriched with arginine residues and S/TPXK sites [28]. The oocyte-specific H1, H1oo, is the longest variant, with an NTD containing multiple potential phosphorylation sites and an extraordinarily long C-terminal tail rich in acidic amino acid residues [24]. Both the N-terminal and globular domains of H1oo are required for correct association with chromatin in the oocyte nucleus [69]. These intrinsic differences among $\mathrm{H} 1$ variants are expected to contribute to their distinct roles in chromatin compaction and gene regulation.

\section{Role of histone H1 variants in mammalian development}

The role of $\mathrm{H} 1$ in development has been interrogated in a variety of organisms. While $\mathrm{H} 1$ is nonessential in unicellular organisms such as yeast and Tetrahymena [80-84], H1 depletion in higher eukaryotes gives rise to more complex phenotypes [85-92], suggesting the involvement of $\mathrm{H} 1$ and its variants in regulation of diverse biological processes. 
During mammalian development, the 11 nonallelic $\mathrm{H} 1$ variants are abundantly expressed and differentially regulated at all stages, from germ cells to embryos and adult tissues, suggesting their fundamental roles in development. The distinct properties of H1 variants as summarized above indicate that they are excellent candidates as mediators of chromatin reprogramming during mammalian development. In this section, we focus our discussions on the expression and functions of mammalian $\mathrm{H} 1$ variants in embryos, adult tissues and germ cells.

\subsection{Embryogenesis}

Mammalian development starts from a zygote, when the egg is fertilized. Fertilization induces the completion of the second meiotic division of the oocyte and the formation of two separate pronuclei within the zygote, i.e., a haploid paternal pronucleus from the sperm and a haploid maternal pronucleus from the oocyte. At this stage, the protamine-bound sperm chromatin becomes decondensed and the protamines are quickly replaced by the oocyte-specific H1, H1oo, leading to an enlarged sperm pronucleus $[24,93]$. The two pronuclei subsequently fuse and cell division ensues.

Before activation of the zygotic genome at the two-cell stage, the oocyte provides the materials necessary for the first cell division. H1oo, the oocyte-specific H1 variant, remains the major $\mathrm{H} 1$ variant present till the late two-cell stage embryo (Fig. 2) [24, 93]. It is surmised that the incorporation of H1oo may facilitate the decondensation of paternal chromatin and nuclear reprogramming after fertilization. Evidence supporting this includes that the Xenopus homolog of $\mathrm{H} 1 \mathrm{oo}, \mathrm{B} 4 / \mathrm{H} 1 \mathrm{M}$, is shown to be crucial for the reactivation of pluripotency genes in somatic nuclei transferred to Xenopus oocytes [94] and that ectopic expression of H1oo-GFP in moue embryonic stem cells (ESCs) leads to increased nuclease sensitivity at specific targets of H1oo- 
GFP [95]. In vitro experiments using Xenopus oocyte extracts showed that B4/H1M is necessary for the architecture and proper segregation of mitotic chromosomes even though it is not required for DNA replication and nuclear envelope assembly [96, 97]. Despite its presumed important roles, $\mathrm{H} 100$ is not required for early embryogenesis in vivo as demonstrated by the lack of observable phenotypes of $\mathrm{H} \mathrm{oo}^{-/-}$mice (Table 3) $[98,99]$. This result is reminiscent of the knockouts of single somatic H1s (Table 3). While the lack of obvious phenotypes in single somatic $\mathrm{H} 1$ knockouts is probably due to the compensation by the remaining somatic $\mathrm{H} 1$ variants (as discussed below), the major somatic H1 variants, H1a-e, are unlikely to compensate upon the deletion of H1oo due to the apparent lack of cross regulation of somatic H1 genes with the H1oo gene.

Surprisingly, the other H1 variant protein abundantly present in the oocyte and the zygote is $\mathrm{H}^{0}$, the replacement $\mathrm{H} 1$ variant accumulated in differentiated cells (Figs 2, 3). $\mathrm{H} 1^{0}$ diminishes at the four-cell stage and is present at minimum levels during early embryogenesis, which is consistent with rapid DNA replication and cell divisions at this stage (Figs 2, 3) [100102]. Similar to $\mathrm{H} 1 \mathrm{oo}^{-/-}$mice, $\mathrm{H} 1^{0}$ null mice are fertile and develop normally, suggesting that $\mathrm{H} 1^{0}$ is not required for early embryogenesis either [103]. These studies suggest that, despite their unique expression patterns and properties in the oocyte and the zygote, $\mathrm{H} 1 \mathrm{oo}$ and $\mathrm{H} 1^{0}$ are dispensable for zygotic genome activation and embryogenesis. Nevertheless, $\mathrm{H} 1$ oo and $\mathrm{H} 1^{0}$ might help define active and inactive transcription domains in the genome and facilitate proper activation of the zygotic genome. The lack of $\mathrm{H} 100$ or $\mathrm{H}^{0}$ may reduce the efficiency of chromatin reprograming in zygotes, even though the surviving $\mathrm{H}_{10 o^{-/-}}$or $\mathrm{H}^{0-/-}$ embryos and mice are not affected. It is also conceivable that the protein synthesis of other $\mathrm{H} 1$ variants is increased in these embryos to compensate for the loss of $\mathrm{H} 1 \mathrm{oo}$ or $\mathrm{H} 1^{0}$. 
Synthesis of other somatic H1s, including H1a, H1b, H1c, H1d and H1e, from the maternal mRNA transcripts starts at late one-cell stage, reaching its maximum rate in early twocell stage embryos (Fig. 2) [104]. The maternal mRNAs of these somatic H1s are degraded in late two-cell embryos, concomitant with the accumulation of their zygotic transcripts [101]. Resumption of somatic H1 proteins occurs during the four-cell stage of embryogenesis, accompanied by the disappearance of H1oo (Fig. 2) [24, 102]. The expression patterns of individual $\mathrm{H} 1$ variants after the four-cell stage have not been fully defined. The incorporation of somatic H1s into chromatin is likely to facilitate proper cell differentiation and germ layer specification during early embryonic development. This is suggested by studies demonstrating important roles of $\mathrm{H} 1$ in ESC differentiation and in loss of mesodermal competence during midblastula to neurula transition in Xenopus $[16,90,105,106]$. HPLC analysis of histone extracts from E10.5 mouse embryos at mid-gestation indicates a total H1-to-nucleosome ratio of 0.74 that is approximately $3 \mathrm{H} 1$ molecules per 4 nucleosomes (Fig. 2) [13]. H1d, H1e and H1b are the most abundant $\mathrm{H} 1 \mathrm{~s}$ at this stage, accounting for $\sim 67 \%$ of the total $\mathrm{H} 1$, whereas $\mathrm{H}^{0}$ is present at a very low level, with an $\mathrm{H} 1^{0}$-to-nucleosome ratio of 0.02 . Given that the accumulation of $\mathrm{H}^{0}$ only occurs in differentiated and non-dividing cells, this expression pattern of $\mathrm{H} 1$ variants is consistent with the rapid cell division in midgestation embryos [13].

The functions of somatic $\mathrm{H} 1$ variants in mammalian embryonic development have been extensively interrogated by targeted gene inactivation. Although somatic H1s are abundant in embryos, mice with single deletion of H1a, H1c, H1d, or H1e produce litters with normal live pups and litter size, suggesting no obvious defects in embryogenesis in these mice (Table 3) [103, 107, 108]. Even in the context of $\mathrm{H}^{0}$ deficiency, further deletion of $\mathrm{H} 1 \mathrm{c}, \mathrm{H} 1 \mathrm{~d}$ or H1e generates mice that are fertile with no obvious phenotypes (Table 3) [108]. Intercrosses of H1c/H1e 
double heterozygous mice produce $\mathrm{H} 1 \mathrm{c} / \mathrm{H} 1 \mathrm{e}$ double null mice at the expected Mendelian ratio, suggesting that compound deletion of H1c and H1e does not interrupt embryogenesis [108]. However, neonatal males of $\mathrm{H} 1 \mathrm{c} / \mathrm{H} 1 \mathrm{e}$ double knockout appear to be smaller than wild-type male littermates. Such phenotype is not observed in neonatal $\mathrm{H}_{1} \mathrm{c}^{-/} \mathrm{H}^{-/ /-}$females [13]. These results suggest that the loss of $\mathrm{H} 1 \mathrm{c} / \mathrm{H} 1 \mathrm{e}$ may not be fully compatible with the rapid growth in male embryos, resulting in moderate impairment in their growth. Due to the compensatory increase of the remaining $\mathrm{H} 1$ variants controlled by yet unknown mechanisms, single or double $\mathrm{H} 1$ deletion does not significantly alter the $\mathrm{H} 1$ content in mouse tissues, suggesting somatic $\mathrm{H} 1$ variants are, at least partially, functionally redundant during embryogenesis and in adult tissues $[13,108]$.

$\mathrm{H} 1^{0} / \mathrm{H} 1 \mathrm{c} / \mathrm{H} 1 \mathrm{e}$ triple homozygous knockout mice are significantly underrepresented in F2 offspring from intercrosses of $\mathrm{H}^{0}$ null mice and $\mathrm{H} 1 \mathrm{c} / \mathrm{H} 1 \mathrm{e}$ double null mice, suggesting that the loss of $\mathrm{H} 1^{0} / \mathrm{H} 1 \mathrm{c} / \mathrm{H} 1 \mathrm{e}$ impairs embryogenesis [13]. Currently it is not determined at which stage during embryogenesis some of the $\mathrm{H}^{0-/} \mathrm{H}^{-/ /} \mathrm{H}^{-/-}$embryos are lost. Nevertheless, the surviving $\mathrm{H} 1 \%$ H1c/H1e triple knockout mice appear normal and fertile despite their mild growth retardation and smaller litter size [13].

The essentiality of histone $\mathrm{H} 1$ in mammalian development was demonstrated by the compound deletion of three major somatic H1 variants, H1c, H1d and H1e. Given that most of somatic $\mathrm{H} 1$ genes are clustered on chromosome 13 in mice (Table 1), a sequential gene targeting

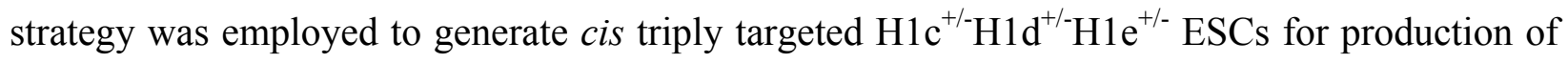
$\mathrm{H} 1 \mathrm{c} / \mathrm{H} 1 \mathrm{~d} / \mathrm{H} 1 \mathrm{e}$ triple knockout mice [13]. H1c/H1d/H1e triple heterozygous $\left(\mathrm{H}_{\mathrm{c}} \mathrm{c}^{+/} \mathrm{H} 1 \mathrm{~d}^{+/} \mathrm{H}_{\mathrm{e}}{ }^{+/}\right.$) mice are fertile and viable, but exhibit growth retardation. $\mathrm{H} 1 \mathrm{c} / \mathrm{H} 1 \mathrm{~d} / \mathrm{H} 1 \mathrm{e}$ triple heterozygotes are

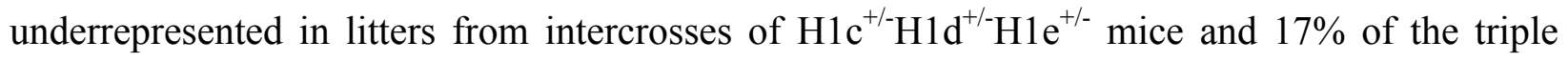
heterozygotes die during embryogenesis [13]. $\mathrm{H}^{-/ /} \mathrm{H}^{-/-} \mathrm{d}^{-/ \mathrm{e}^{-/}}$homozygous mutants are 
underrepresented at $E 7.5$ with increasingly fewer surviving homozygous mutant embryos at the following developmental stages. All triple knockout embryos die by E11.5, indicating embryonic lethality at midgestation. Recovered E9.5 embryos display a broad spectrum of defects, ranging from mild growth restriction and modest developmental delay to severe compromise, such as neural tube aberration, failed chorioallantoic fusion, expanded pericardia, shortened tails and regions of excess tissue [13]. $\mathrm{H}_{1} \mathrm{c}^{-/} \mathrm{H}_{1} \mathrm{~d}^{-/} \mathrm{H} 1 \mathrm{e}^{-/-}$embryos have a $50 \%$ reduction in the total $\mathrm{H} 1$ level at E10.5, suggesting that compensation among somatic $\mathrm{H} 1$ variants is disrupted upon depletion of H1c, H1d and H1e. The embryonic lethality phenotype

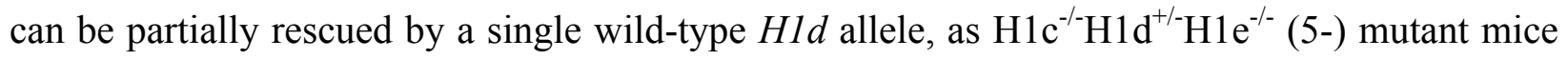
are produced from crosses of $\mathrm{H} 1 \mathrm{c} / \mathrm{H} 1 \mathrm{e}$ double knockout mice with $\mathrm{H} 1 \mathrm{c} / \mathrm{H} 1 \mathrm{~d} / \mathrm{H} 1 \mathrm{e}$ triple heterozygotes. However, the majority of these 5(-) mice die in late embryogenesis and only onethird survive to newborns ([13]; Zhang and Fan, unpublished observation). The surviving 5(-) mutant mice are severely retarded in growth and development [13]. These findings demonstrate that significant functional redundancy exists in the $\mathrm{H} 1$ family and that the total $\mathrm{H} 1$ content, rather than any individual $\mathrm{H} 1$ variants, is essential for mammalian embryogenesis.

\subsection{Tissue-specific functions}

A plethora of studies have shown that the expression of histone $\mathrm{H} 1$ variants varies massively across various tissues and even at different developmental stages of the same tissue (Fig. 2) [13, 20, 108-110]. Given the presence of both replication-dependent and replication-independent H1 variant genes and the multitude levels of transcriptional and translational regulation distinct for each $\mathrm{H} 1$ gene, the relative abundance of mRNA levels of different $\mathrm{H} 1$ variants often does not correlate with the protein composition of $\mathrm{H} 1$ variants in specific cell types or tissues. In any 
specific tissue, the protein composition of $\mathrm{H} 1$ variants is a result of the combinatory effects of the relative proportions of dividing and nondividing cells as well as the complex regulatory mechanisms controlling transcription, mRNA processing and the stability of mRNA and proteins for each $\mathrm{H} 1$ variant [14, 20, 22, 111-113].

Earlier studies using gel electrophoresis, such as two-dimensional polyacrylamide gel electrophoresis (PAGE), acid/urea PAGE and SDS PAGE, to analyze H1 histones extracted from mouse or rat tissues found that H1a through H1e are present in almost all tissues examined, consisting with the ubiquitous expression features of somatic H1s. More recent HPLC analyses of histone extracts allow the separation and quantitative measurement of different histone fractions. Using $\mathrm{H} 2 \mathrm{~B}$ as an internal control, this method provides an accurate assessment of the ratios of H1-to-nucleosome, including ratios of total H1-to-nucleosome and individual H1 variants-to-nucleosome, and standardizes the cross comparisons of the amounts of $\mathrm{H} 1$ variants in different cell types and tissues. Figure 2 summarizes available data on the H1 to nucleosome ratios in adult tissues.

Combining data sets from gel electrophoresis and HPLC analyses, we could note the dramatic increase of $\mathrm{H}^{0}$ and H1e accompanied by the decline of H1a, H1c and H1d during tissue maturation and reduction of cell division. This trend is prominent in liver, lung, kidney and cerebral cortex during development (Fig. 2) [13, 110, 114-116]. For example, $\mathrm{H} 1^{0}$ and H1e account for $9.5 \%$ and $19 \%$ of the total H1, respectively, in neonatal mouse liver, but their compositions reach $29 \%$ and $40 \%$ of the total $\mathrm{H} 1$ in adult liver (Fig. 2) [13]. Likewise, in differentiating cortical neurons, H1e reaches the highest proportion of the total $\mathrm{H} 1$ accompanied by an escalation of $\mathrm{H}^{0}[110,114-116]$. During retinal maturation, however, H1c is markedly upregulated (Fig. 2) [117]. Consistent with the accumulation of $\mathrm{H}^{0}$ upon terminal cell division, 
$\mathrm{H} 1^{0}$ is at minimal levels in tissues maintaining active cell proliferation, such as thymus and spleen. H1c and H1d are abundant in most tissues, including adult thymus and spleen, while the level of H1a is rather low in most adult tissues. The distantly related variant H1x is expressed in all tissues examined [45], however, it is not expressed at a comparable level as other somatic H1s that can be clearly detected by HPLC analysis of histone extracts (Fig. 2).

The distinct regulation of $\mathrm{H} 1$ variants expression and the specific $\mathrm{H} 1$ composition in each tissue during mammalian development may suggest that the abundance and relative proportion of each $\mathrm{H} 1$ variant are important for maintaining proper development and tissue maturation. However, mice deficient of any one of the somatic H1 variants, including those of high abundance in specific tissues, do not display obvious defects in particular tissue functions (Table 3) $[13,103,107,108,117]$. For example, $\mathrm{H} 1 \mathrm{c}$ reaches $30 \%$ of the total $\mathrm{H} 1$ in rod photoreceptors of adult mice, yet $\mathrm{H}^{-/-}$mice have normal rod photoreceptor packing and global heterochromatin condensation in retina [117]. Similarly, H1 proteins in adult liver are largely composed of $\mathrm{H} 1 \mathrm{e}$ and $\mathrm{H}^{0}$ which account for $42 \%$ and $27 \%$ of the total $\mathrm{H} 1$, respectively. The loss of either H1e or $\mathrm{H} 1{ }^{0}$ has no effects on the size or maturation of mouse liver $[13,103]$.

Functional redundancy among $\mathrm{H} 1$ family members and compensation of the lost $\mathrm{H} 1$ variants by the remaining H1s are thought to account for the lack of phenotypes in single knockouts of $\mathrm{H} 1$ variants. Indeed, even when two major somatic $\mathrm{H} 1$ variants are depleted, mice appear to be normal (Table 3). HPLC analysis of histone extracts from mouse tissues indicates that the total $\mathrm{H} 1$ levels in these single and double knockouts remain unchanged, suggesting compensation of the deleted H1s by upregulation of the remaining somatic H1s. For example, $\mathrm{H}^{0}$ and H1e together account for $70 \%$ of the total $\mathrm{H} 1$ in adult liver, yet $\mathrm{H} 1^{0-/} \mathrm{H} 1 \mathrm{e}^{-/-}$double mutant mice appear to be normal with a typical total H1-to-nucleosome ratio of 0.76 in mature 
liver [108]. The compensatory effects are most prominent within the group of $\mathrm{H} 1^{0}$, H1c, H1d and $\mathrm{H} 1 \mathrm{e}$, indicating potential cross regulatory mechanisms among these H1s [13, 103, 107, 108, 117]. These results suggest a large capacity of increased expression and synthesis of the remaining $\mathrm{H} 1$ variants that is sufficient to compensate for the loss of up to two abundant $\mathrm{H} 1$ variants.

Disruption of compensation by compound knockout of more than two major H1 variants leads to severe phenotypes, ranging from mild growth retardation to embryonic lethality as summarized in Table 3. In addition, $\mathrm{H}^{0-/}{ }^{0-} \mathrm{H}_{1} \mathrm{c}^{-/} \mathrm{H} 1 \mathrm{e}^{-/-}$and $\mathrm{H}_{1} \mathrm{c}^{-/-} \mathrm{H}_{1} \mathrm{~d}^{+/} \mathrm{H} 1 \mathrm{e}^{-/-}$mice have smaller thymuses than those of wild-type littermates. HPLC analysis showed a 40-50\% reduction in H1 content in thymus of these mutant mice, suggesting that a low H1 content is not compatible with the rapid cell division in thymus. These studies on compound H1 knockout mice indicate that the total $\mathrm{H} 1$ level is critical for normal tissue development and functions [13].

Despite the compensation among H1 variants and the lack of general defects in single and double knockouts of $\mathrm{H} 1$ variants, emerging evidence suggests that, the loss of single somatic $\mathrm{H} 1$ variants can lead to specific defects. For example, $\mathrm{H}^{0}$ is upregulated during cellular differentiation in all cell types, including dendritic cells $[22,118]$. The deletion of $\mathrm{H}^{0}$ does not lead to general defects in differentiation or cell division in most tissues examined, but specifically impairs production and function of dendritic cells in mutant mice [103, 118]. This apparent lack of compensation of $\mathrm{H} 1^{0}$ by the remaining somatic $\mathrm{H} 1 \mathrm{~s}$ could be due to a potential failure in upregulation of the remaining H1s or may be attributed to specific cellular functions of $\mathrm{H} 1^{0}$ in dendritic cells not directly connected to its general role in chromatin condensation, such as $\mathrm{H}^{0}{ }^{0}$-specific interactions with other proteins [119]. Similarly, $\mathrm{H} 1 \mathrm{c}^{-/-}$mice display increased resistance to x-ray induced apoptosis in thymocytes and intestines, which is connected to H1c 
being a signal transducer in apoptosis induced by DNA double-strand breaks (DSB) [120, 121]. DSB induces the translocation of H1c from the nucleus to the cytoplasm which destabilizes mitochondrial membranes and leads to the release of cytochrome $\mathrm{c}$ and apoptosis [120-122].

\subsection{Gametogenesis}

Gametogenesis is the process of producing haploid gametes from diploid germ cells by meiotic cell division in gonads. It includes spermatogenesis and oogenesis in males and females, respectively. Mammalian gametogenesis is characterized by distinct chromatin remodeling and condensation processes where histone $\mathrm{H} 1$ plays a fundamental role [123].

Spermatogenesis has three phases: 1) spermatogonia renewal and proliferation, in which spermatogonial stem cells undergo multiplication to form preleptotene primary spermatocytes; 2) meiosis, in which preleptotene primary spermatocytes enter meiosis to form round spermatids; 3 ) spermiogenesis, in which spermatids undergo dramatic morphological changes to form elongated spermatozoa [124]. Chromatin condensation during spermatogenesis is mediated by a unique set of male germ cell specific proteins, including testis-specific linker histones, transition proteins and protamines [123]. During spermatogenesis, somatic H1 variants are progressively replaced by testis-specific H1 variants, followed by the replacement of most histones with transition proteins and protamines, resulting in dramatic chromatin condensation culminating in mature spermatozoa.

Spermatogonia express a complement of somatic H1 variants, mainly H1a and H1c [25,

125]. H1a is the predominant $\mathrm{H} 1$ variant in prepachytene spermatocytes, comprising approximately $70 \%$ of the total $\mathrm{H} 1$ [25], but its level steadily decreases in meiotic spermatocytes 
and postmeiotic spermatids until it fully disappears (Fig. 3) [126]. H1t, the testis-specific H1 variant, starts to accumulate in pachytene spermatocytes and persists until round spermatids, constituting up to $55 \%$ of the total H1 (Figs 2, 3) [127-130]. Both H1a and H1t have relatively low chromatin binding affinity and are weak chromatin condensers [51-53, 73-75], which presumably contributes to the adoption of loosely compacted chromatin in early spermatocytes followed by a relatively open chromatin in pachytene spermatocytes and facilitates the genetic recombination in pachytene spermatocytes and/or the replacement of histones with transition proteins in early spermatids [131]. However, despite their unique expression patterns and abundance during these developmental stages, H1a and H1t appear to be dispensable for spermatogenesis. Mice lacking H1a or H1t are fertile and show normal spermatogenesis [107, 132-134]. HPLC analysis indicates that the total amount of $\mathrm{H} 1$ proteins in $\mathrm{H}^{-a^{-/}}$and $\mathrm{H} 1 \mathrm{t}^{-/-}$mice remain unchanged. Interestingly, the loss of H1a is mainly compensated by increased expression of other somatic $\mathrm{H} 1$ variants, $\mathrm{H} 1 \mathrm{c}, \mathrm{H} 1 \mathrm{~d}$ and $\mathrm{H} 1 \mathrm{e}$, whereas the loss of H1t is compensated by upregulation of H1a and H1c [133, 135]. Depletion of both H1a and H1t, which together account for nearly $70 \%$ of the total $\mathrm{H} 1$ in male germ cells, disrupts the biochemical compensation and leads to a $25 \%$ decrease in the total $\mathrm{H} 1$ level. Such depletion causes specific changes in gene expression in germ cells without overt phenotypes in $\mathrm{H} 1 \mathrm{a}^{-/-} \mathrm{H} 1 \mathrm{t}^{-/}$mice, which are fertile and have normal spermatogenesis [135]. No defects in homologous chromosome pairing and recombination or differences in chromatin condensation are observed in male germ cells of $\mathrm{H} 1 \mathrm{a} / \mathrm{H} 1 \mathrm{t}$ double knockout mice, further demonstrating that $\mathrm{H} 1 \mathrm{a}$ and $\mathrm{H} 1 \mathrm{t}$ are dispensable for chromatin condensation and structural changes during spermatogenesis [135]. In $\mathrm{H} \mathrm{a}^{-/ /} \mathrm{H} 1 \mathrm{t}^{-/-}$ male germ cells, major somatic H1 variants, H1c, H1d and H1e, are markedly upregulated, 
suggesting potential roles of somatic H1s in spermatogenesis and in compensating for the loss of H1s specific for or enriched in spermatogenesis.

The other two testis-specific H1 variants, H1T2 and HILS1, are most distantly related and least conserved H1 variants (Table 2). The expression of H1T2 and HILS1 is confined to spermatids (Fig. 3) [26-29]. H1T2 is present in the nuclei of early spermatids and has a particular polarized localization in round and elongating spermatids, associated with chromatin at the apical pole of the spermatid nucleus [26]. The loss of H1T2 in mice severely impairs chromatin condensation and the morphological transformation of round spermatids $[26,28]$. These results demonstrate that H1T2 is required for normal spermiogenesis and plays a critical role in chromatin condensation and in establishing cell polarity of elongating spermatids $[26,28]$. H1T2 has been found to interact with protamines and its elimination leads to a decrease in protamine content, suggesting a functional role of H1T2 in histone-to-protamine transition [28]. H1T2 and the histone methyltransferase Ezh2 have been found to interact and colocalize at the apical poles of round spermatids, which may suggest a role of H1T2 in chromatin remodeling through regulating histone H3K27 methylation during spermatid elongation [136].

HILS1 is expressed in early and elongated spermatids, and its nuclear localization largely overlaps with that of transition proteins and protamines (Fig. 3) [27]. HILS1 has a higher DNA binding affinity than $\mathrm{H} 1 \mathrm{~T} 2$, which may contribute to the increased chromatin condensation in late spermatids [28]. No knockout study has been reported for HILS1. Nonetheless, decreased expression of HILS1 in sperms was found to be associated with reduced sperm mobility in human males, offering a potential link between HILS1 and male fertility [137].

Similar to spermatogenesis, the maternal germline stem cells, oogonia, go through mitotic and meiotic phases to produce fertilizable eggs. However, oogenesis does not involve a 
spectacular chromatin condensation process as observed in spermatogenesis. Instead, oocytes sustain a chromatin structure much like somatic cells. Oogonia express a complement of somatic H1s, including H1a-e and $\mathrm{H}^{0}$. Starting from the meiotic phase, H1a-e are gradually replaced by the oocyte-specific H1oo (Fig. 2) [24, 101]. The aforementioned unique expression pattern and properties of H1oo suggest that it may have a special role in organizing chromatin structure during oocyte maturation. Indeed, knockdown of H1oo expression by microinjection of antisense morpholino oligonucleotides against H1oo into mouse oocytes or injection of H1oo siRNA into bovine oocytes dramatically impairs first polar body extrusion and meiotic maturation of germinal vesicle stage oocytes in vitro $[138,139]$. Such defects can be rescued by H1oo, but not somatic H1s, indicating the requirement of H1oo for proper meiotic progression during oogenesis $[138,139]$. However, $\mathrm{H}_{100}{ }^{-/-}$mice do not exhibit obvious phenotypes [98, 99], demonstrating that the loss of H1oo can be tolerated in vivo during oogenesis (Table 3). Further examination of chromatin and meiosis maturation of oocytes from $\mathrm{H}_{10 o^{-/-}}$mice will help elucidate processes and regulatory mechanisms of chromatin remodeling during mammalian oogenesis.

Although $\mathrm{H} 1^{0}$ is retained throughout oogenesis [100-102], the role of $\mathrm{H} 1^{0}$ in this process is not clear. $\mathrm{H} 1^{0}$ null mice are fertile [103], suggesting that $\mathrm{H} 1^{0}$ is dispensable. As discussed above for other developmental stages, the lack of phenotypes in single H1 knockouts is likely due to the compensation by the remaining somatic $\mathrm{H} 1$ variants. The mRNA transcripts of somatic H1s are present in meiotic oocytes and persist until newly fertilized embryos [100, 101], serving as a reservoir for $\mathrm{H} 1$ synthesis before zygotic genome activation in early embryos.

In summary, gametogenesis involves a series of chromatin and morphological reorganization steps to produce fertilizable germ cells. The replacement of somatic H1s with 
germ cell-specific counterparts suggests that germ cell-specific H1s play a critical role in sperm and oocyte production. Given their distinct biochemical properties from somatic H1s, germ cellspecific $\mathrm{H} 1$ variants are likely to mediate or participate in the dramatic chromatin remodeling processes occurring in gametogenesis. However, their exact roles in these processes and early embryogenesis remain underexplored and warrant further investigation.

\section{Role of linker histone $\mathrm{H} 1$ in stem cell differentiation}

Stem cells have the remarkable potential to give rise to different cell types in mammalian tissues. According to their differentiation capacity, stem cells can be categorized into two major groups: pluripotent stem cells such as embryonic stem cells (ESCs) derived from the inner cell mass of a blastocyst, which have the potential to differentiate into all cell types in the body, and adult stem cells, which exist in specific tissues and are capable to generate certain cell types in the tissues. Stem cells are fundamental to embryonic development and tissue generation and can serve as great in vitro systems for studying the regulatory mechanisms controlling these processes. Progenitor cells, the early descendants of adult stem cells, have limited capacity in self-renewal and differentiation. Recent studies have uncovered linker histones as important regulators for differentiation of embryonic stem cells and progenitor cells.

Pluripotent stem cells have an open chromatin state with globally hyperactive transcription and undergo chromatin condensation upon differentiation, rendering the chromatin less permissive to transcription [140-142]. Differentiation of pluripotent stem cells involves dramatic molecular changes, including silencing of pluripotency genes and activation of lineagespecific genes [143], as well as global chromatin remodeling and epigenetic reprogramming [144, 145]. FRAP studies have shown that ESCs are characterized by hyperdynamic binding of 
chromatin proteins, such as linker histones and heterochromatin protein 1 (HP1), and that ESC differentiation is accompanied by a reduction in the mobility of these proteins $[141,146]$. The rapid exchange of $\mathrm{H} 1$ proteins appears to be required for ESC differentiation to proceed, as overexpression of an $\mathrm{H}^{0}$ protein with a tandem duplication of CTD for restricting its mobility perturbed ESC differentiation [141]. It is surmised that hyperdynamic binding of H1 and other chromatin proteins provides a "breathing" window rendering the chromatin more accessible to remodeling factors in response to differentiation signals [141]. The high H1 mobility in ESCs may be achieved through citrullination, which neutralizes positive charges and results in a reduced binding affinity for chromatin. Peptidylarginine deiminase 4 (PADI4) catalyzes citrullination on arginine 54 within the globular domain of H1c (H1.2), H1d (H1.3) and H1e (H1.4). PADI4 expression is restricted to pluripotent stem cells and necessary to maintain pluripotency transcriptional network [147]. These findings suggest that $\mathrm{H1}$ dynamics plays a fundamental role in regulating chromatin plasticity during ESC differentiation.

The role of $\mathrm{H} 1$ dynamics in modulating differentiation is not exclusive to pluripotent stem cells, but has also been shown in murine erythroleukemia (MEL) cells, an excellent model for studying terminal cell differentiation [148]. Concomitant with MEL differentiation is the dramatic increase in $\mathrm{H}^{0}$ and $\mathrm{H} 1 \mathrm{c}$ levels [149] as well as the increased chromatin binding affinity of all histone $\mathrm{H} 1$ variants [150]. H1 phosphorylation by cyclin-dependent kinase (CDK) destabilizes H1-chromatin interactions and reduces its binding to chromatin $[48,151,152]$. Overexpression of $\mathrm{H}^{0}$ mutants mimicking the constitutively phosphorylated $\mathrm{H} 1$ sufficiently inhibits MEL differentiation, demonstrating that dephosphorylation of $\mathrm{H} 1$ is necessary for erythroid differentiation. It is proposed that $\mathrm{H} 1$ phosphorylation in MEL cells may cause an 
alteration in local chromatin structure without the displacement of $\mathrm{H} 1$ from chromatin as observed for H1 citrullination in ESCs [150].

During ESC differentiation, not only is the mobility of $\mathrm{H} 1$ reduced, but also the level of total $\mathrm{H} 1$ is progressively increased. ESCs have a total H1-to-nucleosome ratio of around 0.46, compared with that above 0.7 in differentiated cells $[13,15,153]$. During embryoid body (EB) differentiation of ESCs, the H1-to-nucleosome ratio increases to 0.62 (Table 3) [16]. The increase in the total $\mathrm{H} 1$ level during ESC differentiation is due to the elevation in protein levels of H1c, H1d, H1e and $\mathrm{H}^{0}{ }^{0}$ [16], which likely contributes to chromatin condensation. The dynamic changes in $\mathrm{H} 1$ expression suggest histone $\mathrm{H} 1$ and its variants as important modulators of cellular differentiation. However, deletion of $\mathrm{H} 1 \mathrm{c}, \mathrm{H} 1 \mathrm{~d}, \mathrm{H} 1 \mathrm{e}$, or $\mathrm{H} 1^{0}$, despite a slight decrease in the total H1 level in mouse ESCs, does not impair ESC differentiation (Table 3) ([154] and Pan, Zhang, Fan unpublished observations). This is consistent with the findings from single H1 knockout studies that individual $\mathrm{H} 1$ variants are not required for mammalian development (see Section 2.1). Nevertheless, $\mathrm{H} 1^{0}$ (H1.0) knockdown in human ESCs impairs the induction of HNF4, Sox 17 and FoxA2, genes associated with differentiation [106], suggesting a potential role of $\mathrm{H1}{ }^{0}$ in regulating specific genes during human ESC differentiation.

The important role of $\mathrm{H} 1$ in ESC differentiation has been demonstrated in $\mathrm{H} 1 \mathrm{c} / \mathrm{H} 1 \mathrm{~d} / \mathrm{H} 1 \mathrm{e}$ triple null ESCs. These ESCs, derived from $\mathrm{H1} / \mathrm{c} 1 \mathrm{~d} / \mathrm{H} 1 \mathrm{e}$ triple knockout (H1 TKO) blastocysts, have $50 \%$ reduction in the total $\mathrm{H} 1$ level, offering a useful system to test the necessity of $\mathrm{H} 1$ in ESC differentiation $[16,105,153]$. The loss of H1c, H1d and H1e does not appear to affect selfrenewal or expression of pluripotency factors in undifferentiated ESCs, and H1 TKO ESCs display growth rate, cell morphology and overall transcriptome characteristic of WT ESCs [16, 153]. However, H1 TKO ESCs are more resistant to spontaneous differentiation, and H1 TKO 
EBs are impaired in producing cells and morphologies of three primitive germ layers (Table 3) [16]. When induced for neural differentiation, putative H1 TKO EBs display severe defects in neurite outgrowth and the induction of neural lineage specific genes. A common theme in the various differentiation schemes is the failure in effective repression of pluripotency genes such as Oct4 and Nanog in H1 TKOs, which also occurs in vivo in H1 TKO embryos [16]. H1 TKO ESCs are dysregulated in specification of mesendoderm and neuroectoderm [105], further suggesting specific effects of $\mathrm{H} 1$ in these lineages. The fact that $\mathrm{H} 1$ occupancy at the promoter region of the pluripotency gene Oct4 increases during ESC differentiation and that the loss of $\mathrm{H} 1$ impairs DNA methylation and changes of histone marks at this region necessary for Oct4 silencing suggests $\mathrm{H} 1$ as a critical regulator for epigenetic silencing of Oct4 $[16,106]$. Thus, the effects of $\mathrm{H} 1$ on the silencing of pluripotency genes are likely to be direct.

Other evidence establishes specific $\mathrm{H} 1$ variants as important regulators for differentiation of progenitor cells. During terminal differentiation of retinal cells in mice, the expression of H1c, along with $\mathrm{H}^{0}$ and $\mathrm{H} 1 \mathrm{e}$, is dramatically increased, contributing to the highly compact heterochromatin and nuclear architecture in mouse rod cells [117]. Although the loss of H1c does not lead to abnormalities in rod cell differentiation, H1c/H1e double knockouts and $\mathrm{H} 1^{0} / \mathrm{H} 1 \mathrm{c} / \mathrm{H} 1 \mathrm{e}$ triple knockouts displayed defects in rod development and rod cell packing, presumably due to the impairment in the terminal differentiation of rod photoreceptors.

While aforementioned studies suggest the necessity of a sufficient total H1 level for proper differentiation, $\mathrm{H} 1 \mathrm{~b}$ has been found to participate in the inhibition of myogenesis during myoblast differentiation $[90,155]$. H1b is specifically recruited by the homeoprotein Msx 1 to the core enhancer region of the $M y o D$ gene, which establishes a repressive chromatin state at the $M y o D$ gene locus and inhibits the expression of $M y o D$ and myogenic differentiation of myoblast 
C2C12 cells [155]. Knockdown of H1b by shRNA abolishes the Msx1-mediated repression of myogenic differentiation, and coexpression of Msx 1 and $\mathrm{H} 1 \mathrm{~b}$ in Xenopus embryos synergistically inhibits Xenopus MyoD [155]. These results are reminiscent of the previous findings in Xenopus embryos where inhibition of the accumulation of Xenopus H1c (xH1c), the ortholog of mouse H1b, by ribozymes, leads to the failure in loss of mesodermal competence and the lack of $M y o D$ silencing [90]. The effects appear to be specific to H1b, as injection of H1e into Xenopus embryos does not inhibit MyoD expression [155].

\section{Potential mechanisms of histone $\mathrm{H} 1$ in the regulation of mammalian development and stem cell differentiation}

The broad defects in mammalian development and stem cell differentiation uncovered through H1 manipulation as discussed above suggest that $\mathrm{H} 1$ plays crucial and versatile roles in these processes. While the exact mechanisms underlying the regulatory roles of $\mathrm{H} 1$ in these processes remain to be explored, a few potential mechanisms can be gleaned from the studies of functions of $\mathrm{H} 1$ in chromatin structure and gene expression.

Chromatin structure undergoes dramatic changes during development and cellular

differentiation. As a key architectural chromatin protein, H1 modulates the bulk chromatin structure in various aspects, such as chromatin condensation, nucleosome repeat length (NRL), histone modifications and chromatin dynamicity. The H1 stoichiometry is positively correlated with nucleosome repeat length (NRL) (reviewed in ref. [15]), both of which are key determinants of the degree of chromatin compaction [156]. Higher H1 content leads to a longer NRL and more compact chromatin fibers, while H1 depletion causes reduction in NRL and chromatin decondensation $[13,109,117,153,157]$. The $\mathrm{H} 1$ content progressively increases during stem 
cell differentiation or terminal cell differentiation, as shown in the total H1-to-nucleosome ratio changing from 0.45 in ESCs to 0.62 in differentiating EBs, or from 1.02 in new born retina to 1.25 in adult retinal cells (Fig. 2, Table 3) [16, 117]. H1 stoichiometry regulates histone modifications in bulk chromatin as shown for specific histone methylations and histone acetylation $[153,158,159]$. The $\mathrm{H} 1$ level is also pivotal for promoting heterochromatin formation, such as the establishment and proper function of pericentric heterochromatin and chromocenter clustering [86, 109, 159-162].

The amount and modifications of $\mathrm{H} 1$ histones can regulate chromatin dynamicity. Chromatin in pluripotent stem cells is found to be hyperdynamic [141]. The proper level of chromatin flexibility and dynamicity seems to be necessary for chromatin remodeling during development and cellular differentiation, as both the increase of $\mathrm{H} 1$ binding affinity in ESCs (by overexpression of the $\mathrm{H} 1^{0}$ mutant with two C-terminal domains) and the failure to increase $\mathrm{H} 1$ binding by dephosphorylation during MEL differentiation (by overexpression of a $\mathrm{H}^{0}$ mutant mimicking the constitutively phosphorylated $\mathrm{H}^{0}{ }^{\circ}$ ) inhibit cellular differentiation in respective mouse ESCs and erythroleukemia cells $[141,146,150]$. In addition, H1 depletion reduces chromatin flexibility in gene-rich topologically associating domains (TADs) [163].

It is not determined if any or all of the aspects of bulk chromatin structure per se are responsible for the defects in development and cell differentiation displayed in compound $\mathrm{H} 1$ knockouts. The lack of overall phenotype in vivo in single knockouts, combined with increasingly more severe phenotypes caused by more dramatic depletion of $\mathrm{H} 1$ in compound knockouts, establishes a compensatory effect among the H1 family and a common role of $\mathrm{H} 1$ variants in development and cellular differentiation. These results, together with the studies showing the necessity of $\mathrm{H} 1$ in chromatin architecture and assembly of mitotic chromosomes as 
well as the roles of $\mathrm{H} 1$ in pericentromeric heterochromatin function and proper chromocenter clustering $[86,97,109,164]$, indicate that H1's regulatory roles in bulk chromatin structure could contribute to general cell functionality required for robust development and proper cell differentiation.

In contrast to its global effects on bulk chromatin, H1 plays rather specific roles in gene regulation in vivo. Even though early studies with in vitro constituted chromatin indicate a general repressive role of $\mathrm{H} 1$ for transcription by all three types of RNA polymerases (reviewed in $[165,166])$, depletion of $\mathrm{H} 1$ in a variety of organisms and cells shows limited gene expression changes in vivo [81, 84, 135, 153, 167]. rRNA genes, transgenes, major satellites and genes at pericentromeric regions, imprinted genes, sex chromosome genes and pluripotency genes, as well as developmental genes important for embryogenesis and gametogenesis, have been characterized as target genes of $\mathrm{H} 1$ in various systems $[16,85,88,90,91,109,153-155,168$ 171]. Interestingly, these genes are often subjected to epigenetic regulation.

Indeed, recent studies have established $\mathrm{H} 1$ as an important epigenetic factor for gene regulation. Genes affected by triple deletion of $\mathrm{H} 1 \mathrm{c} / \mathrm{H} 1 \mathrm{~d} / \mathrm{H} 1 \mathrm{e}$ in ESCs are enriched in genes normally regulated by DNA methylation, and H1 depletion leads to hypomethylation at the regulatory regions of these H1-regulated genes, such as the imprinting control regions (ICR) of H19/Igf2 and Gtl2/Dlk loci in ESCs [153]. These results reveal a novel link between H1 and DNA methylation, which was also strengthened by studies on the immunoglobulin heavy chain locus [172], the Rhox gene cluster [170] and the pluripotency gene Oct4 locus [154]. The identification of DNA methyltransferases DNMT1 and DNMT3B as H1 interacting partners further provides a mechanism for $\mathrm{H} 1$ regulating DNA methylation through direct recruitment of DNMTs $[173,174]$. Likewise, H1 has been shown in various studies to regulate histone 
modifications by interaction with histone modifying enzymes, including PRC2-Ezh2 polycomb complex, which catalyzes H3K27 di- and tri- methylation [175-178], SirT1, a histone deacetylase preferentially targeting to H3K9Ac and H4K16Ac [179, 180], and Cul4A, an E3 ubiquitin ligase responsible for H4K31 ubiquitination [62]. H1 occupancy can also prevent the binding of certain histone modifying enzymes to specific regulatory loci [174]. Nevertheless, given the general non-DNA-sequence-dependent nature for the binding of H1, DNMTs, and histone modifying enzymes to DNA, how the specificity is achieved at these target gene loci remains elusive. It is noteworthy that many of these H1-regulated genes, such as imprinted genes, are particularly sensitive to local changes in chromatin structure and epigenetic modifications, with a lower threshold for eliciting changes in gene expression and epigenetic states.

H1 variants may also participate in specific gene regulation in a variant-specific manner. As mentioned earlier, H1 variants have distinct expression patterns during development and cell differentiation. They differ from each other in amino acid sequence, biochemical property and binding affinity for chromatin, which may confer specificity in chromatin compaction, protein interactions and gene regulation (See Section 1). While genome-wide mapping studies of H1 variants categorize $\mathrm{H} 1$ binding as a repressive epigenetic mark by its positive correlation with repressive histone marks, such as $\mathrm{H} 3 \mathrm{~K} 9 \mathrm{me} 3$, and negative correlation with active histone marks, such as $\mathrm{H} 3 \mathrm{~K} 4 \mathrm{me} 3$, different $\mathrm{H} 1$ variants do have distinct enriched regions despite their overall co-localization and common binding patterns at the genome-wide scale $[109,181,182]$. Indeed, it has been shown that in vivo occupancy of H1a (H1.1) and H1d (H1.3) differ dramatically at the regulatory region of $\mathrm{H} 19$ gene [171], suggesting that distinct binding by different $\mathrm{H} 1$ variants 
could contribute to the establishment and maintenance of epigenetic patterns and gene regulation at specific loci.

H1 variants may interact with transcription factors, resulting in specific gene regulation of the target genes of those regulatory proteins. The best examples come from studies on H1c (H1.2) and H1b (H1.5). H1c was found to repress p53 target genes in HeLa cells through its interaction with p53, a group of cofactors, and ribosomal proteins [61]. During early embryogenesis, H1c forms a complex with CHD8 to suppress p53-mediated transcription and apoptosis [169]. H1b interacts with the homeoprotein Msx1 to repress myoD expression, thus inhibiting myogenic differentiation in myoblast $\mathrm{C} 2 \mathrm{C} 12$ cells and mesodermal competence in Xenopus animal caps $[90,155]$. On the other hand, H1b was found to bind forkhead box transcription factor FoxP3 in human regulatory $\mathrm{T}$ (Treg) cells to regulate the expression of FoxP3 target genes, such as IL2 and CTL4, thus modulating Treg function [183]. In the human promonocytic THP-1 cells, H1b binds to NF- $\mathrm{kB}$ factor RelB and forms a repressor complex at the promoters of $T N F-\alpha$ and $I L-1 \beta$, silencing these proinflammatory genes [184]. These results suggest that $\mathrm{H} 1$ variants regulate specific gene expression in a context dependent manner.

A variety of other specific roles of $\mathrm{H} 1$ variants in cellular processes in mammalian cells have been identified. For instance, $\mathrm{H} 1^{0}$ (H1.0) was found to preferentially interact with a group of proteins in the nucleolus, indicating a specific role of $\mathrm{H}^{0}$ in rRNA biogenesis and mRNA metabolism [119]. Other than the aforementioned role of $\mathrm{H} 1$ in apoptosis through regulating p53 and CHD8 target genes, H1c was shown to translocate from the nucleus to the cytoplasm and stimulate cytochrome $\mathrm{c}$ release from mitochondria upon DSB damage, thus acting as a signal transducer in apoptosis induced by DSB [120]. More recently, H1c and H1x have been found to be ubiquitinated at $\mathrm{K} 63$ and that $\mathrm{H} 1$ is a key target for E3 ubiquitin ligase RNF8 and E2 
ubiquitin-conjugating enzyme UBC13 in DSB signaling [185]. In addition, H1 may stimulate non-homologous end-joining and homologous recombination mediated repair after DNA damage $[186,187]$.

Most of the mechanistic studies mentioned in this section were carried out in cell lines, which are more amiable for genetic manipulation and environmental stimuli. It is not yet clear whether any or all of the specific roles of $\mathrm{H1}$ variants discussed here are responsible for the phenotypes observed in mammalian development and stem cell differentiation in compound $\mathrm{H} 1$ knockouts. Future studies in in vivo setting to identify the key regulatory pathways that are responsible for the defects in compound $\mathrm{H} 1$ knockouts should provide new insights.

\section{Concluding remarks and future directions}

During the past decades, we have seen an enormous amount of advances in the understanding of chromatin structure and function, especially in connection with chromatin modifying activities and chromatin remodeling complexes. Compared with core histones, linker histones have not drawn adequate attention and thus remain underexplored [57]. Investigating the role of H1 variants in mammalian development and stem cell differentiation in vivo as well as the underlying mechanisms has been challenging partly due to the complexity/heterogeneity and the compensatory effects of mammalian $\mathrm{H} 1$ variants and the lack of antibodies of high affinity and specificity for $\mathrm{H} 1$ variants and their post-translational modifications. However, a plethora of recent studies as summarized in this review have shed significant new insights on the role of $\mathrm{H} 1$ in these processes. 
We have focused our discussion on the pivotal roles of $\mathrm{H} 1$ in mammalian development, including embryogenesis, tissue maturation and gametogenesis, and also reviewed its role in stem cell differentiation with connection to development. These studies establish that the total $\mathrm{H} 1$ level, rather than individual $\mathrm{H} 1 \mathrm{~s}$, is critical for viability and robust development and required for proper ESC differentiation. There is significant redundancy and compensation among somatic H1 variants during development. While the regulatory circuit governing the compensation among somatic H1s remains poorly understood, such redundancy suggest commonality in their structural and functional roles at the genome-wide scale, which is also supported by their largely overlapping genomic localization in multiple cell types $[109,181$, 182]. On the other hand, the high sequence conservation and the exquisite differential expression patterns of $\mathrm{H} 1$ variants are indicative of an amazing evolutionary adaption. The presence of multiple $\mathrm{H} 1$ variants may also provide a powerful cushion for potential perturbations in chromatin milieu.

Disruption of the compensation among somatic H1s results in global effects on chromatin structure but specific gene expression changes $[13,16,103,107,108,132-135,154]$. The mechanisms underlying the global vs. specific effects regulated by $\mathrm{H} 1$ are important avenues to pursue. New links between $\mathrm{H} 1$ and other epigenetic regulatory mechanisms are likely to emerge from future studies. In addition, identification of key $\mathrm{H} 1$ target genes and the signaling pathways involved in physiological and pathological contexts should lead to new insights into the role of H1.

Given their differences in biochemical properties, interaction partners, chromatin binding affinity and spatial temporal expression patterns, $\mathrm{H} 1$ variants are bound to have distinct functions, probably in a specific and context-dependent manner, in development and cellular differentiation. 
These differential properties of $\mathrm{H} 1$ variants offer a means to 'fine-tune' the regulation of chromatin structures and gene expression, culminated in optimal physiological performance and response to environmental stress. Indeed, such variant-specific functions may be especially important in diseases, such as cancers and immunological diseases, as nicely illustrated by the prominent effects arising from manipulation of $\mathrm{H} 1$ variants in cancer cells and the identification of $\mathrm{H} 1$ variant mutations as driver mutations in tumors [167, 171, 188-191]. Future research aimed at $\mathrm{H} 1$ variant-specific functions in the context of various diseases should provide novel insights into the role of $\mathrm{H} 1$ variants in mammalian development and cellular differentiation. 


\section{Acknowledgements}

We apologize to all colleagues whose work could not be directly cited here due to restrictions on references and space limitations. This work is in part supported by NIH grant GM085261 (Y. Fan), Georgia Research Alliance Distinguished Cancer Scientists Award (Y. Fan), Chen Fellowship, NSF Science and Technology Center Emergent Behaviors of Integrated Cellular Systems (EBICS; CBET0939511), and Georgia Institute of Technology. 


\section{References}

[1] A.P. Wolffe, H. Kurumizaka, The nucleosome: a powerful regulator of transcription, Progress in nucleic acid research and molecular biology, 61 (1998) 379-422.

[2] C.A. Davey, D.F. Sargent, K. Luger, A.W. Maeder, T.J. Richmond, Solvent mediated interactions in the structure of the nucleosome core particle at 1.9 a resolution, J Mol Biol, 319 (2002) 1097-1113.

[3] J.T. Finch, A. Klug, Solenoidal model for superstructure in chromatin, Proc Natl Acad Sci U S A, 73 (1976) 1897-1901.

[4] F. Thoma, T. Koller, A. Klug, Involvement of histone H1 in the organization of the nucleosome and of the salt-dependent superstructures of chromatin, J Cell Biol, 83 (1979) 403427.

[5] A.P. Wolffe, Histone H1, Int J Biochem Cell Biol, 29 (1997) 1463-1466.

[6] A.L. Olins, D.E. Olins, Spheroid chromatin units (v bodies), Science, 183 (1974) 330-332.

[7] D.T. Brown, Histone variants: are they functionally heterogeneous?, Genome Biol, 2 (2001) REVIEWS0006.

[8] M.H. Parseghian, B.A. Hamkalo, A compendium of the histone H1 family of somatic subtypes: an elusive cast of characters and their characteristics, Biochem Cell Biol, 79 (2001) 289-304.

[9] S.M. Seyedin, W.S. Kistler, H1 histone subfractions of mammalian testes. 1. Organ specificity in the rat, Biochemistry, 18 (1979) 1371-1375.

[10] W. Albig, T. Meergans, D. Doenecke, Characterization of the H1.5 gene completes the set of human H1 subtype genes, Gene, 184 (1997) 141-148.

[11] M.H. Parseghian, A.H. Henschen, K.G. Krieglstein, B.A. Hamkalo, A proposal for a coherent mammalian histone H1 nomenclature correlated with amino acid sequences, Protein science : a publication of the Protein Society, 3 (1994) 575-587.

[12] P.B. Talbert, K. Ahmad, G. Almouzni, J. Ausio, F. Berger, P.L. Bhalla, W.M. Bonner, W.Z. Cande, B.P. Chadwick, S.W. Chan, G.A. Cross, L. Cui, S.I. Dimitrov, D. Doenecke, J.M. EirinLopez, M.A. Gorovsky, S.B. Hake, B.A. Hamkalo, S. Holec, S.E. Jacobsen, K. Kamieniarz, S. Khochbin, A.G. Ladurner, D. Landsman, J.A. Latham, B. Loppin, H.S. Malik, W.F. Marzluff, J.R. Pehrson, J. Postberg, R. Schneider, M.B. Singh, M.M. Smith, E. Thompson, M.E. TorresPadilla, D.J. Tremethick, B.M. Turner, J.H. Waterborg, H. Wollmann, R. Yelagandula, B. Zhu, S. Henikoff, A unified phylogeny-based nomenclature for histone variants, Epigenetics \& chromatin, 5 (2012) 7.

[13] Y. Fan, T. Nikitina, E.M. Morin-Kensicki, J. Zhao, T.R. Magnuson, C.L. Woodcock, A.I. Skoultchi, H1 linker histones are essential for mouse development and affect nucleosome spacing in vivo, Mol Cell Biol, 23 (2003) 4559-4572.

[14] Z.F. Wang, A.M. Sirotkin, G.M. Buchold, A.I. Skoultchi, W.F. Marzluff, The mouse histone H1 genes: gene organization and differential regulation, J Mol Biol, 271 (1997) 124-138. [15] C.L. Woodcock, A.I. Skoultchi, Y. Fan, Role of linker histone in chromatin structure and function: H1 stoichiometry and nucleosome repeat length, Chromosome Res, 14 (2006) 17-25.

[16] Y. Zhang, M. Cooke, S. Panjwani, K. Cao, B. Krauth, P.Y. Ho, M. Medrzycki, D.T. Berhe, C. Pan, T.C. McDevitt, Y. Fan, Histone h1 depletion impairs embryonic stem cell differentiation, PLoS Genet, 8 (2012) e1002691. 
[17] S. Khochbin, Histone H1 diversity: bridging regulatory signals to linker histone function, Gene, 271 (2001) 1-12.

[18] J.S. Godde, K. Ura, Dynamic alterations of linker histone variants during development, Int J Dev Biol, 53 (2009) 215-224.

[19] S. Perez-Montero, A. Carbonell, F. Azorin, Germline-specific H1 variants: the "sexy" linker histones, Chromosoma, (2015).

[20] R.W. Lennox, L.H. Cohen, The histone H1 complements of dividing and nondividing cells of the mouse, J Biol Chem, 258 (1983) 262-268.

[21] D. Doenecke, W. Albig, H. Bouterfa, B. Drabent, Organization and expression of H1 histone and H1 replacement histone genes, Journal of cellular biochemistry, 54 (1994) 423-431.

[22] J. Zlatanova, D. Doenecke, Histone H1 zero: a major player in cell differentiation?, FASEB J, 8 (1994) 1260-1268.

[23] S. Stoldt, D. Wenzel, E. Schulze, D. Doenecke, N. Happel, G1 phase-dependent nucleolar accumulation of human histone H1x, Biology of the cell / under the auspices of the European Cell Biology Organization, 99 (2007) 541-552.

[24] M. Tanaka, J.D. Hennebold, J. Macfarlane, E.Y. Adashi, A mammalian oocyte-specific linker histone gene H1oo: homology with the genes for the oocyte-specific cleavage stage histone (cs-H1) of sea urchin and the B4/H1M histone of the frog, Development, 128 (2001) 655-664.

[25] R.W. Lennox, L.H. Cohen, The alterations in H1 histone complement during mouse spermatogenesis and their significance for H1 subtype function, Dev Biol, 103 (1984) 80-84.

[26] I. Martianov, S. Brancorsini, R. Catena, A. Gansmuller, N. Kotaja, M. Parvinen, P. SassoneCorsi, I. Davidson, Polar nuclear localization of H1T2, a histone H1 variant, required for spermatid elongation and DNA condensation during spermiogenesis, Proc Natl Acad Sci U S A, 102 (2005) 2808-2813.

[27] W. Yan, L. Ma, K.H. Burns, M.M. Matzuk, HILS1 is a spermatid-specific linker histone H1-like protein implicated in chromatin remodeling during mammalian spermiogenesis, Proc Natl Acad Sci U S A, 100 (2003) 10546-10551.

[28] H. Tanaka, N. Iguchi, A. Isotani, K. Kitamura, Y. Toyama, Y. Matsuoka, M. Onishi, K. Masai, M. Maekawa, K. Toshimori, M. Okabe, Y. Nishimune, HANP1/H1T2, a novel histone H1-like protein involved in nuclear formation and sperm fertility, Mol Cell Biol, 25 (2005) 71077119.

[29] N. Iguchi, H. Tanaka, K. Yomogida, Y. Nishimune, Isolation and characterization of a novel cDNA encoding a DNA-binding protein (Hils1) specifically expressed in testicular haploid germ cells, International journal of andrology, 26 (2003) 354-365.

[30] N. Iguchi, H. Tanaka, S. Yamada, H. Nishimura, Y. Nishimune, Control of mouse hils1 gene expression during spermatogenesis: identification of regulatory element by transgenic mouse, Biol Reprod, 70 (2004) 1239-1245.

[31] M.L. Whitfield, L.X. Zheng, A. Baldwin, T. Ohta, M.M. Hurt, W.F. Marzluff, Stem-loop binding protein, the protein that binds the $3^{\prime}$ end of histone mRNA, is cell cycle regulated by both translational and posttranslational mechanisms, Mol Cell Biol, 20 (2000) 4188-4198.

[32] W.F. Marzluff, P. Gongidi, K.R. Woods, J. Jin, L.J. Maltais, The human and mouse replication-dependent histone genes, Genomics, 80 (2002) 487-498.

[33] J. Ling, S.J. Morley, V.M. Pain, W.F. Marzluff, D.R. Gallie, The histone 3'-terminal stemloop-binding protein enhances translation through a functional and physical interaction with eukaryotic initiation factor 4G (eIF4G) and eIF3, Mol Cell Biol, 22 (2002) 7853-7867. 
[34] B. Gorgoni, S. Andrews, A. Schaller, D. Schumperli, N.K. Gray, B. Muller, The stem-loop binding protein stimulates histone translation at an early step in the initiation pathway, RNA, 11 (2005) 1030-1042.

[35] P. Allard, Q. Yang, W.F. Marzluff, H.J. Clarke, The stem-loop binding protein regulates translation of histone mRNA during mammalian oogenesis, Dev Biol, 286 (2005) 195-206.

[36] G.H. Cheng, A. Nandi, S. Clerk, A.I. Skoultchi, Different 3'-end processing produces two independently regulated mRNAs from a single H1 histone gene, Proc Natl Acad Sci U S A, 86 (1989) 7002-7006.

[37] Z.F. Wang, T. Krasikov, M.R. Frey, J. Wang, A.G. Matera, W.F. Marzluff, Characterization of the mouse histone gene cluster on chromosome 13: 45 histone genes in three patches spread over 1Mb, Genome Res, 6 (1996) 688-701.

[38] W. Albig, D. Doenecke, The human histone gene cluster at the D6S105 locus, Human genetics, 101 (1997) 284-294.

[39] W. Albig, P. Kioschis, A. Poustka, K. Meergans, D. Doenecke, Human histone gene organization: nonregular arrangement within a large cluster, Genomics, 40 (1997) 314-322.

[40] A. Volz, W. Albig, D. Doenecke, A. Ziegler, Physical mapping of two histone gene clusters on human chromosome 6p22.1-22.2, DNA sequence : the journal of DNA sequencing and mapping, 8 (1997) 173-179.

[41] G.E. Chapman, P.G. Hartman, E.M. Bradbury, Studies on the role and mode of operation of the very-lysine-rich histone $\mathrm{H} 1$ in eukaryote chromatin. The isolation of the globular and nonglobular regions of the histone H1 molecule, in: Eur J Biochem, vol. 61, 1976, pp. 69-75.

[42] J. Allan, P.G. Hartman, C. Crane-Robinson, F.X. Aviles, The structure of histone H1 and its location in chromatin, Nature, 288 (1980) 675-679.

[43] V. Ramakrishnan, J.T. Finch, V. Graziano, P.L. Lee, R.M. Sweet, Crystal structure of globular domain of histone H5 and its implications for nucleosome binding, Nature, 362 (1993) 219-223.

[44] B. Drabent, K. Franke, C. Bode, U. Kosciessa, H. Bouterfa, H. Hameister, D. Doenecke, Isolation of two murine $\mathrm{H} 1$ histone genes and chromosomal mapping of the H1 gene complement, Mammalian genome : official journal of the International Mammalian Genome Society, 6 (1995) 505-511.

[45] T. Yamamoto, M. Horikoshi, Cloning of the cDNA encoding a novel subtype of histone H1, Gene, 173 (1996) 281-285.

[46] N. Happel, E. Schulze, D. Doenecke, Characterisation of human histone H1x, Biol Chem, 386 (2005) 541-551.

[47] J. Allan, T. Mitchell, N. Harborne, L. Bohm, C. Crane-Robinson, Roles of H1 domains in determining higher order chromatin structure and H1 location, J Mol Biol, 187 (1986) 591-601.

[48] M.J. Hendzel, M.A. Lever, E. Crawford, J.P. Th'ng, The C-terminal domain is the primary determinant of histone H1 binding to chromatin in vivo, J Biol Chem, 279 (2004) 20028-20034.

[49] A. Luque, R. Collepardo-Guevara, S. Grigoryev, T. Schlick, Dynamic condensation of linker histone C-terminal domain regulates chromatin structure, Nucleic Acids Res, 42 (2014) 7553-7560.

[50] P. Vyas, D.T. Brown, N- and C-terminal domains determine differential nucleosomal binding geometry and affinity of linker histone isotypes H1(0) and H1c, J Biol Chem, 287 (2012) 11778-11787. 
[51] J. Clausell, N. Happel, T.K. Hale, D. Doenecke, M. Beato, Histone H1 subtypes differentially modulate chromatin condensation without preventing ATP-dependent remodeling by SWI/SNF or NURF, PLoS One, 4 (2009) e0007243.

[52] M. Orrego, I. Ponte, A. Roque, N. Buschati, X. Mora, P. Suau, Differential affinity of mammalian histone H1 somatic subtypes for DNA and chromatin, BMC biology, 5 (2007) 22.

[53] J.P. Th'ng, R. Sung, M. Ye, M.J. Hendzel, H1 family histones in the nucleus. Control of binding and localization by the C-terminal domain, J Biol Chem, 280 (2005) 27809-27814.

[54] F. Catez, T. Ueda, M. Bustin, Determinants of histone H1 mobility and chromatin binding in living cells, Nat Struct Mol Biol, 13 (2006) 305-310.

[55] N. Happel, D. Doenecke, Histone H1 and its isoforms: contribution to chromatin structure and function, Gene, 431 (2009) 1-12.

[56] A. Izzo, K. Kamieniarz, R. Schneider, The histone H1 family: specific members, specific functions?, Biol Chem, 389 (2008) 333-343.

[57] S.W. Harshman, N.L. Young, M.R. Parthun, M.A. Freitas, H1 histones: current perspectives and challenges, Nucleic Acids Res, 41 (2013) 9593-9609.

[58] S.J. McBryant, X. Lu, J.C. Hansen, Multifunctionality of the linker histones: an emerging role for protein-protein interactions, Cell research, 20 (2010) 519-528.

[59] H.J. Szerlong, J.A. Herman, C.M. Krause, J.G. DeLuca, A. Skoultchi, Q.A. Winger, J.E. Prenni, J.C. Hansen, Proteomic characterization of the nucleolar linker histone H1 interaction network, J Mol Biol, 427 (2015) 2056-2071.

[60] J.Q. Ni, L.P. Liu, D. Hess, J. Rietdorf, F.L. Sun, Drosophila ribosomal proteins are associated with linker histone H1 and suppress gene transcription, Genes Dev, 20 (2006) 19591973.

[61] K. Kim, J. Choi, K. Heo, H. Kim, D. Levens, K. Kohno, E.M. Johnson, H.W. Brock, W. An, Isolation and characterization of a novel H1.2 complex that acts as a repressor of p53-mediated transcription, J Biol Chem, 283 (2008) 9113-9126.

[62] K. Kim, B. Lee, J. Kim, J. Choi, J.M. Kim, Y. Xiong, R.G. Roeder, W. An, Linker Histone H1.2 cooperates with Cul4A and PAF1 to drive H4K31 ubiquitylation-mediated transactivation, Cell reports, 5 (2013) 1690-1703.

[63] W. An, S.H. Leuba, K. van Holde, J. Zlatanova, Linker histone protects linker DNA on only one side of the core particle and in a sequence-dependent manner, Proc Natl Acad Sci U S A, 95 (1998) 3396-3401.

[64] Y.B. Zhou, S.E. Gerchman, V. Ramakrishnan, A. Travers, S. Muyldermans, Position and orientation of the globular domain of linker histone H5 on the nucleosome, Nature, 395 (1998) 402-405.

[65] D.T. Brown, T. Izard, T. Misteli, Mapping the interaction surface of linker histone H1(0) with the nucleosome of native chromatin in vivo, Nat Struct Mol Biol, 13 (2006) 250-255.

[66] L. Fan, V.A. Roberts, Complex of linker histone H5 with the nucleosome and its implications for chromatin packing, Proc Natl Acad Sci U S A, 103 (2006) 8384-8389.

[67] B.R. Zhou, J. Jiang, H. Feng, R. Ghirlando, T.S. Xiao, Y. Bai, Structural Mechanisms of Nucleosome Recognition by Linker Histones, Mol Cell, 59 (2015) 628-638.

[68] X. Lu, B. Hamkalo, M.H. Parseghian, J.C. Hansen, Chromatin condensing functions of the linker histone $\mathrm{C}$-terminal domain are mediated by specific amino acid composition and intrinsic protein disorder, Biochemistry, 48 (2009) 164-172.

[69] M. Becker, A. Becker, F. Miyara, Z. Han, M. Kihara, D.T. Brown, G.L. Hager, K. Latham, E.Y. Adashi, T. Misteli, Differential in vivo binding dynamics of somatic and oocyte-specific 
linker histones in oocytes and during ES cell nuclear transfer, Molecular biology of the cell, 16 (2005) 3887-3895.

[70] C. Wood, A. Snijders, J. Williamson, C. Reynolds, J. Baldwin, M. Dickman, Posttranslational modifications of the linker histone variants and their association with cell mechanisms, The FEBS journal, 276 (2009) 3685-3697.

[71] J.F. Kepert, J. Mazurkiewicz, G.L. Heuvelman, K.F. Toth, K. Rippe, NAP1 modulates binding of linker histone $\mathrm{H} 1$ to chromatin and induces an extended chromatin fiber conformation, J Biol Chem, 280 (2005) 34063-34072.

[72] A. Lusser, D.L. Urwin, J.T. Kadonaga, Distinct activities of CHD1 and ACF in ATPdependent chromatin assembly, Nat Struct Mol Biol, 12 (2005) 160-166.

[73] F. De Lucia, M.R. Faraone-Mennella, M. D'Erme, P. Quesada, P. Caiafa, B. Farina, Histone-induced condensation of rat testis chromatin: testis-specific H1t versus somatic H1 variants, Biochem Biophys Res Commun, 198 (1994) 32-39.

[74] J.R. Khadake, M.R. Rao, DNA- and chromatin-condensing properties of rat testes H1a and H1t compared to those of rat liver H1bdec; H1t is a poor condenser of chromatin, Biochemistry, 34 (1995) 15792-15801.

[75] H. Talasz, N. Sapojnikova, W. Helliger, H. Lindner, B. Puschendorf, In vitro binding of H1 histone subtypes to nucleosomal organized mouse mammary tumor virus long terminal repeat promotor, J Biol Chem, 273 (1998) 32236-32243.

[76] M.M. Bharath, N.R. Chandra, M.R. Rao, Prediction of an HMG-box fold in the C-terminal domain of histone H1: insights into its role in DNA condensation, Proteins, 49 (2002) 71-81.

[77] T.L. Caterino, J.J. Hayes, Structure of the H1 C-terminal domain and function in chromatin condensation, Biochem Cell Biol, 89 (2011) 35-44.

[78] M.M. Pradeepa, M.R. Rao, Chromatin remodeling during mammalian spermatogenesis: role of testis specific histone variants and transition proteins, Society of Reproduction and Fertility supplement, 63 (2007) 1-10.

[79] S. Ramesh, M.M. Bharath, N.R. Chandra, M.R. Rao, A K52Q substitution in the globular domain of histone H1t modulates its nucleosome binding properties, FEBS Lett, 580 (2006) 5999-6006.

[80] H.G. Patterton, C.C. Landel, D. Landsman, C.L. Peterson, R.T. Simpson, The biochemical and phenotypic characterization of Hholp, the putative linker histone H1 of Saccharomyces cerevisiae, J Biol Chem, 273 (1998) 7268-7276.

[81] K. Hellauer, E. Sirard, B. Turcotte, Decreased expression of specific genes in yeast cells lacking histone H1, J Biol Chem, 276 (2001) 13587-13592.

[82] J.A. Downs, E. Kosmidou, A. Morgan, S.P. Jackson, Suppression of homologous recombination by the Saccharomyces cerevisiae linker histone, Mol Cell, 11 (2003) 1685-1692.

[83] X. Shen, L. Yu, J.W. Weir, M.A. Gorovsky, Linker histones are not essential and affect chromatin condensation in vivo, Cell, 82 (1995) 47-56.

[84] X. Shen, M.A. Gorovsky, Linker histone H1 regulates specific gene expression but not global transcription in vivo, Cell, 86 (1996) 475-483.

[85] M.A. Jedrusik, E. Schulze, A single histone H1 isoform (H1.1) is essential for chromatin silencing and germline development in Caenorhabditis elegans, Development, 128 (2001) 10691080.

[86] X. Lu, S.N. Wontakal, A.V. Emelyanov, P. Morcillo, A.Y. Konev, D.V. Fyodorov, A.I. Skoultchi, Linker histone H1 is essential for Drosophila development, the establishment of 
pericentric heterochromatin, and a normal polytene chromosome structure, Genes Dev, 23 (2009) 452-465.

[87] S. Perez-Montero, A. Carbonell, T. Moran, A. Vaquero, F. Azorin, The embryonic linker histone $\mathrm{H} 1$ variant of Drosophila, dBigH1, regulates zygotic genome activation, Developmental cell, 26 (2013) 578-590.

[88] P. Bouvet, S. Dimitrov, A.P. Wolffe, Specific regulation of Xenopus chromosomal 5S rRNA gene transcription in vivo by histone H1, Genes Dev, 8 (1994) 1147-1159.

[89] H. Kandolf, The H1A histone variant is an in vivo repressor of oocyte-type 5S gene transcription in Xenopus laevis embryos, Proc Natl Acad Sci U S A, 91 (1994) 7257-7261.

[90] O.C. Steinbach, A.P. Wolffe, R.A. Rupp, Somatic linker histones cause loss of mesodermal competence in Xenopus, Nature, 389 (1997) 395-399.

[91] M. Prymakowska-Bosak, M.R. Przewloka, J. Slusarczyk, M. Kuras, J. Lichota, B. Kilianczyk, A. Jerzmanowski, Linker histones play a role in male meiosis and the development of pollen grains in tobacco, The Plant cell, 11 (1999) 2317-2329.

[92] M.R. Przewloka, A.T. Wierzbicki, J. Slusarczyk, M. Kuras, K.D. Grasser, C. Stemmer, A. Jerzmanowski, The "drought-inducible" histone H1s of tobacco play no role in male sterility linked to alterations in H1 variants, Planta, 215 (2002) 371-379.

[93] S. Gao, Y.G. Chung, M.H. Parseghian, G.J. King, E.Y. Adashi, K.E. Latham, Rapid H1 linker histone transitions following fertilization or somatic cell nuclear transfer: evidence for a uniform developmental program in mice, Dev Biol, 266 (2004) 62-75.

[94] J. Jullien, C. Astrand, R.P. Halley-Stott, N. Garrett, J.B. Gurdon, Characterization of somatic cell nuclear reprogramming by oocytes in which a linker histone is required for pluripotency gene reactivation, Proc Natl Acad Sci U S A, 107 (2010) 5483-5488.

[95] K. Hayakawa, J. Ohgane, S. Tanaka, S. Yagi, K. Shiota, Oocyte-specific linker histone H1foo is an epigenomic modulator that decondenses chromatin and impairs pluripotency, Epigenetics, 7 (2012) 1029-1036.

[96] M. Dasso, S. Dimitrov, A.P. Wolffe, Nuclear assembly is independent of linker histones, Proc Natl Acad Sci U S A, 91 (1994) 12477-12481.

[97] T.J. Maresca, B.S. Freedman, R. Heald, Histone H1 is essential for mitotic chromosome architecture and segregation in Xenopus laevis egg extracts, J Cell Biol, 169 (2005) 859-869.

[98] M. Kihara, N. Kirkman, E.Y. Adashi, G. King, Oocytes from H1 foo knockout mice develop normally, in: MGI Direct Data Submission, 2005, http://www.informatics.jax.org/reference/J:101326.

[99] W.T.S. Institute, Alleles produced for the KOMP project by the Wellcome Trust Sanger Institute, in: MGI Direct Data Submission, 2009, http://www.informatics.jax.org/reference/J:148605.

[100] H.J. Clarke, M. Bustin, C. Oblin, Chromatin modifications during oogenesis in the mouse: removal of somatic subtypes of histone $\mathrm{H} 1$ from oocyte chromatin occurs post-natally through a post-transcriptional mechanism, J Cell Sci, 110 ( Pt 4) (1997) 477-487.

[101] H.J. Clarke, D.W. McLay, O.A. Mohamed, Linker histone transitions during mammalian oogenesis and embryogenesis, Developmental genetics, 22 (1998) 17-30.

[102] G. Fu, P. Ghadam, A. Sirotkin, S. Khochbin, A.I. Skoultchi, H.J. Clarke, Mouse oocytes and early embryos express multiple histone H1 subtypes, Biol Reprod, 68 (2003) 1569-1576.

[103] A.M. Sirotkin, W. Edelmann, G. Cheng, A. Klein-Szanto, R. Kucherlapati, A.I. Skoultchi, Mice develop normally without the H1(0) linker histone, Proc Natl Acad Sci U S A, 92 (1995) 6434-6438. 
[104] M. Wiekowski, M. Miranda, J.Y. Nothias, M.L. DePamphilis, Changes in histone synthesis and modification at the beginning of mouse development correlate with the establishment of chromatin mediated repression of transcription, J Cell Sci, 110 ( Pt 10) (1997) 1147-1158.

[105] G.D. Nguyen, S. Gokhan, A.E. Molero, S.M. Yang, B.J. Kim, A.I. Skoultchi, M.F. Mehler, The role of $\mathrm{H} 1$ linker histone subtypes in preserving the fidelity of elaboration of mesendodermal and neuroectodermal lineages during embryonic development, PLoS One, 9 (2014) e96858.

[106] J.M. Terme, B. Sese, L. Millan-Arino, R. Mayor, J.C. Belmonte, M.J. Barrero, A. Jordan, Histone $\mathrm{H} 1$ variants are differentially expressed and incorporated into chromatin during differentiation and reprogramming to pluripotency, J Biol Chem, 286 (2011) 35347-35357.

[107] S. Rabini, K. Franke, P. Saftig, C. Bode, D. Doenecke, B. Drabent, Spermatogenesis in mice is not affected by histone H1.1 deficiency, Experimental cell research, 255 (2000) 114-124. [108] Y. Fan, A. Sirotkin, R.G. Russell, J. Ayala, A.I. Skoultchi, Individual somatic H1 subtypes are dispensable for mouse development even in mice lacking the H1(0) replacement subtype, Mol Cell Biol, 21 (2001) 7933-7943.

[109] K. Cao, N. Lailler, Y. Zhang, A. Kumar, K. Uppal, Z. Liu, E.K. Lee, H. Wu, M. Medrzycki, C. Pan, P.Y. Ho, G.P. Cooper, Jr., X. Dong, C. Bock, E.E. Bouhassira, Y. Fan, Highresolution mapping of h1 linker histone variants in embryonic stem cells, PLoS Genet, 9 (2013) e1003417.

[110] V. Dominguez, B. Pina, P. Suau, Histone H1 subtype synthesis in neurons and neuroblasts, Development, 115 (1992) 181-185.

[111] K. Franke, B. Drabent, D. Doenecke, Expression of murine H1 histone genes during postnatal development, Biochimica et biophysica acta, 1398 (1998) 232-242.

[112] J.R. Pehrson, R.D. Cole, Histone H1 subfractions and H10 turnover at different rates in nondividing cells, Biochemistry, 21 (1982) 456-460.

[113] S. Khochbin, C. Gorka, J.J. Lawrence, Multiple control level governing H10 mRNA and protein accumulation, FEBS Lett, 283 (1991) 65-67.

[114] B. Pina, P. Martinez, L. Simon, P. Suau, Differential kinetics of histone H1(0) accumulation in neuronal and glial cells from rat cerebral cortex during postnatal development, Biochem Biophys Res Commun, 123 (1984) 697-702.

[115] B. Pina, P. Martinez, P. Suau, Changes in H1 complement in differentiating rat-brain cortical neurons, Eur J Biochem, 164 (1987) 71-76.

[116] L.M. Garcia-Segura, S. Luquin, P. Martinez, M.T. Casas, P. Suau, Differential expression and gonadal hormone regulation of histone $\mathrm{H} 1(0)$ in the developing and adult rat brain, Brain research. Developmental brain research, 73 (1993) 63-70.

[117] E.Y. Popova, S.A. Grigoryev, Y. Fan, A.I. Skoultchi, S.S. Zhang, C.J. Barnstable, Developmentally regulated linker histone $\mathrm{H} 1 \mathrm{c}$ promotes heterochromatin condensation and mediates structural integrity of rod photoreceptors in mouse retina, J Biol Chem, 288 (2013) 17895-17907.

[118] D.I. Gabrilovich, P. Cheng, Y. Fan, B. Yu, E. Nikitina, A. Sirotkin, M. Shurin, T. Oyama, Y. Adachi, S. Nadaf, D.P. Carbone, A.I. Skoultchi, H1(0) histone and differentiation of dendritic cells. A molecular target for tumor-derived factors, J Leukoc Biol, 72 (2002) 285-296.

[119] A.A. Kalashnikova, D.D. Winkler, S.J. McBryant, R.K. Henderson, J.A. Herman, J.G. DeLuca, K. Luger, J.E. Prenni, J.C. Hansen, Linker histone H1.0 interacts with an extensive network of proteins found in the nucleolus, Nucleic Acids Res, 41 (2013) 4026-4035. 
[120] A. Konishi, S. Shimizu, J. Hirota, T. Takao, Y. Fan, Y. Matsuoka, L. Zhang, Y. Yoneda, Y. Fujii, A.I. Skoultchi, Y. Tsujimoto, Involvement of histone H1.2 in apoptosis induced by DNA double-strand breaks, Cell, 114 (2003) 673-688.

[121] A. Cascone, C. Bruelle, D. Lindholm, P. Bernardi, O. Eriksson, Destabilization of the outer and inner mitochondrial membranes by core and linker histones, PLoS One, 7 (2012) e35357.

[122] H. Okamura, K. Yoshida, B.R. Amorim, T. Haneji, Histone H1.2 is translocated to mitochondria and associates with Bak in bleomycin-induced apoptotic cells, Journal of cellular biochemistry, 103 (2008) 1488-1496.

[123] S. Kimmins, P. Sassone-Corsi, Chromatin remodelling and epigenetic features of germ cells, Nature, 434 (2005) 583-589.

[124] Y. Clermont, Kinetics of spermatogenesis in mammals: seminiferous epithelium cycle and spermatogonial renewal, Physiological reviews, 52 (1972) 198-236.

[125] L.R. Bucci, W.A. Brock, M.L. Meistrich, Distribution and synthesis of histone 1 subfractions during spermatogenesis in the rat, Experimental cell research, 140 (1982) 111-118.

[126] K. Franke, B. Drabent, D. Doenecke, Testicular expression of the mouse histone H1.1 gene, Histochem Cell Biol, 109 (1998) 383-390.

[127] M.L. Meistrich, L.R. Bucci, P.K. Trostle-Weige, W.A. Brock, Histone variants in rat spermatogonia and primary spermatocytes, Dev Biol, 112 (1985) 230-240.

[128] K. Steger, T. Klonisch, K. Gavenis, B. Drabent, D. Doenecke, M. Bergmann, Expression of mRNA and protein of nucleoproteins during human spermiogenesis, Molecular human reproduction, 4 (1998) 939-945.

[129] B. Drabent, C. Bode, B. Bramlage, D. Doenecke, Expression of the mouse testicular histone gene H1t during spermatogenesis, Histochem Cell Biol, 106 (1996) 247-251.

[130] B. Drabent, C. Bode, N. Miosge, R. Herken, D. Doenecke, Expression of the mouse histone gene H1t begins at premeiotic stages of spermatogenesis, Cell and tissue research, 291 (1998) 127-132.

[131] D. Churikov, I.A. Zalenskaya, A.O. Zalensky, Male germline-specific histones in mouse and man, Cytogenetic and genome research, 105 (2004) 203-214.

[132] B. Drabent, P. Saftig, C. Bode, D. Doenecke, Spermatogenesis proceeds normally in mice without linker histone H1t, Histochem Cell Biol, 113 (2000) 433-442.

[133] Q. Lin, A. Sirotkin, A.I. Skoultchi, Normal spermatogenesis in mice lacking the testisspecific linker histone H1t, Mol Cell Biol, 20 (2000) 2122-2128.

[134] D.A. Fantz, W.R. Hatfield, G. Horvath, M.K. Kistler, W.S. Kistler, Mice with a targeted disruption of the H1t gene are fertile and undergo normal changes in structural chromosomal proteins during spermiogenesis, Biol Reprod, 64 (2001) 425-431.

[135] Q. Lin, A. Inselman, X. Han, H. Xu, W. Zhang, M.A. Handel, A.I. Skoultchi, Reductions in linker histone levels are tolerated in developing spermatocytes but cause changes in specific gene expression, J Biol Chem, 279 (2004) 23525-23535.

[136] R. Lambrot, S. Jones, S. Saint-Phar, S. Kimmins, Specialized distribution of the histone methyltransferase Ezh2 in the nuclear apical region of round spermatids and its interaction with the histone variant H1t2, Journal of andrology, 33 (2012) 1058-1066.

[137] P. Jedrzejczak, B. Kempisty, A. Bryja, M. Mostowska, M. Depa-Martynow, L. Pawelczyk, P.P. Jagodzinski, Quantitative assessment of transition proteins 1, 2 spermatid-specific linker histone H1-like protein transcripts in spermatozoa from normozoospermic and asthenozoospermic men, Archives of andrology, 53 (2007) 199-205. 
[138] M. Furuya, M. Tanaka, T. Teranishi, K. Matsumoto, Y. Hosoi, K. Saeki, H. Ishimoto, K. Minegishi, A. Iritani, Y. Yoshimura, H1foo is indispensable for meiotic maturation of the mouse oocyte, The Journal of reproduction and development, 53 (2007) 895-902.

[139] Y. Yun, P. An, J. Ning, G.M. Zhao, W.L. Yang, A.M. Lei, H1foo is essential for in vitro meiotic maturation of bovine oocytes, Zygote, 23 (2015) 416-425.

[140] S. Efroni, R. Duttagupta, J. Cheng, H. Dehghani, D.J. Hoeppner, C. Dash, D.P. BazettJones, S. Le Grice, R.D. McKay, K.H. Buetow, T.R. Gingeras, T. Misteli, E. Meshorer, Global transcription in pluripotent embryonic stem cells, Cell stem cell, 2 (2008) 437-447.

[141] E. Meshorer, D. Yellajoshula, E. George, P.J. Scambler, D.T. Brown, T. Misteli, Hyperdynamic plasticity of chromatin proteins in pluripotent embryonic stem cells, Developmental cell, 10 (2006) 105-116.

[142] A. Gaspar-Maia, A. Alajem, E. Meshorer, M. Ramalho-Santos, Open chromatin in pluripotency and reprogramming, Nat Rev Mol Cell Biol, 12 (2011) 36-47.

[143] D.A. Loebel, C.M. Watson, R.A. De Young, P.P. Tam, Lineage choice and differentiation in mouse embryos and embryonic stem cells, Dev Biol, 264 (2003) 1-14.

[144] R. Jaenisch, A. Bird, Epigenetic regulation of gene expression: how the genome integrates intrinsic and environmental signals, Nat Genet, 33 Suppl (2003) 245-254.

[145] T.P. Rasmussen, Embryonic stem cell differentiation: a chromatin perspective, Reproductive biology and endocrinology : RB\&E, 1 (2003) 100.

[146] S. Melcer, H. Hezroni, E. Rand, M. Nissim-Rafinia, A. Skoultchi, C.L. Stewart, M. Bustin, E. Meshorer, Histone modifications and lamin A regulate chromatin protein dynamics in early embryonic stem cell differentiation, Nature communications, 3 (2012) 910.

[147] M.A. Christophorou, G. Castelo-Branco, R.P. Halley-Stott, C.S. Oliveira, R. Loos, A. Radzisheuskaya, K.A. Mowen, P. Bertone, J.C. Silva, M. Zernicka-Goetz, M.L. Nielsen, J.B. Gurdon, T. Kouzarides, Citrullination regulates pluripotency and histone $\mathrm{H} 1$ binding to chromatin, Nature, 507 (2014) 104-108.

[148] A.S. Tsiftsoglou, I.S. Pappas, I.S. Vizirianakis, Mechanisms involved in the induced differentiation of leukemia cells, Pharmacology \& therapeutics, 100 (2003) 257-290.

[149] W. Helliger, H. Lindner, O. Grubl-Knosp, B. Puschendorf, Alteration in proportions of histone $\mathrm{H} 1$ variants during the differentiation of murine erythroleukaemic cells, The Biochemical journal, 288 ( Pt 3) (1992) 747-751.

[150] D. Yellajoshyula, D.T. Brown, Global modulation of chromatin dynamics mediated by dephosphorylation of linker histone $\mathrm{H} 1$ is necessary for erythroid differentiation, Proc Natl Acad Sci U S A, 103 (2006) 18568-18573.

[151] A. Contreras, T.K. Hale, D.L. Stenoien, J.M. Rosen, M.A. Mancini, R.E. Herrera, The dynamic mobility of histone $\mathrm{H} 1$ is regulated by cyclin/CDK phosphorylation, Mol Cell Biol, 23 (2003) 8626-8636.

[152] C.S. Hill, J.M. Rimmer, B.N. Green, J.T. Finch, J.O. Thomas, Histone-DNA interactions and their modulation by phosphorylation of -Ser-Pro-X-Lys/Arg- motifs, EMBO J, 10 (1991) 1939-1948.

[153] Y. Fan, T. Nikitina, J. Zhao, T.J. Fleury, R. Bhattacharyya, E.E. Bouhassira, A. Stein, C.L. Woodcock, A.I. Skoultchi, Histone H1 depletion in mammals alters global chromatin structure but causes specific changes in gene regulation, Cell, 123 (2005) 1199-1212.

[154] Y. Zhang, Z. Liu, M. Medrzycki, K. Cao, Y. Fan, Reduction of Hox gene expression by histone H1 depletion, PLoS One, 7 (2012) e38829. 
[155] H. Lee, R. Habas, C. Abate-Shen, MSX1 cooperates with histone H1b for inhibition of transcription and myogenesis, Science, 304 (2004) 1675-1678.

[156] A. Routh, S. Sandin, D. Rhodes, Nucleosome repeat length and linker histone stoichiometry determine chromatin fiber structure, Proc Natl Acad Sci U S A, 105 (2008) 88728877.

[157] A. Gunjan, D.T. Brown, Overproduction of histone H1 variants in vivo increases basal and induced activity of the mouse mammary tumor virus promoter, Nucleic Acids Res, 27 (1999) 3355-3363.

[158] A. Gunjan, D.B. Sittman, D.T. Brown, Core histone acetylation is regulated by linker histone stoichiometry in vivo, J Biol Chem, 276 (2001) 3635-3640.

[159] X. Lu, S.N. Wontakal, H. Kavi, B.J. Kim, P.M. Guzzardo, A.V. Emelyanov, N. Xu, G.J. Hannon, J. Zavadil, D.V. Fyodorov, A.I. Skoultchi, Drosophila H1 regulates the genetic activity of heterochromatin by recruitment of Su(var)3-9, Science, 340 (2013) 78-81.

[160] A.L. Nielsen, M. Oulad-Abdelghani, J.A. Ortiz, E. Remboutsika, P. Chambon, R. Losson, Heterochromatin formation in mammalian cells: interaction between histones and HP1 proteins, Mol Cell, 7 (2001) 729-739.

[161] S. Daujat, U. Zeissler, T. Waldmann, N. Happel, R. Schneider, HP1 binds specifically to Lys26-methylated histone H1.4, whereas simultaneous Ser27 phosphorylation blocks HP1 binding, J Biol Chem, 280 (2005) 38090-38095.

[162] T.K. Hale, A. Contreras, A.J. Morrison, R.E. Herrera, Phosphorylation of the linker histone H1 by CDK regulates its binding to HP1alpha, Mol Cell, 22 (2006) 693-699.

[163] V. Ea, T. Sexton, T. Gostan, L. Herviou, M.O. Baudement, Y. Zhang, S. Berlivet, M.N. Le Lay-Taha, G. Cathala, A. Lesne, J.M. Victor, Y. Fan, G. Cavalli, T. Forne, Distinct polymer physics principles govern chromatin dynamics in mouse and Drosophila topological domains, BMC genomics, 16 (2015) 607.

[164] H. Hashimoto, Y. Takami, E. Sonoda, T. Iwasaki, H. Iwano, M. Tachibana, S. Takeda, T. Nakayama, H. Kimura, Y. Shinkai, Histone H1 null vertebrate cells exhibit altered nucleosome architecture, Nucleic Acids Res, 38 (2010) 3533-3545.

[165] A. Wolffe, Chromatin : Structure and Function Elsevier Science \& Technology Books, 1999.

[166] M. Vignali, J.L. Workman, Location and function of linker histones, Nature structural biology, 5 (1998) 1025-1028.

[167] M. Sancho, E. Diani, M. Beato, A. Jordan, Depletion of human histone H1 variants uncovers specific roles in gene expression and cell growth, PLoS Genet, 4 (2008) e1000227.

[168] R. Alami, Y. Fan, S. Pack, T.M. Sonbuchner, A. Besse, Q. Lin, J.M. Greally, A.I. Skoultchi, E.E. Bouhassira, Mammalian linker-histone subtypes differentially affect gene expression in vivo, Proc Natl Acad Sci U S A, 100 (2003) 5920-5925.

[169] M. Nishiyama, K. Oshikawa, Y. Tsukada, T. Nakagawa, S. Iemura, T. Natsume, Y. Fan, A. Kikuchi, A.I. Skoultchi, K.I. Nakayama, CHD8 suppresses p53-mediated apoptosis through histone H1 recruitment during early embryogenesis, Nat Cell Biol, 11 (2009) 172-182.

[170] J.A. Maclean, A. Bettegowda, B.J. Kim, C.H. Lou, S.M. Yang, A. Bhardwaj, S. Shanker, Z. Hu, Y. Fan, S. Eckardt, K.J. McLaughlin, A.I. Skoultchi, M.F. Wilkinson, The rhox homeobox gene cluster is imprinted and selectively targeted for regulation by histone $\mathrm{hl}$ and DNA methylation, Mol Cell Biol, 31 (2011) 1275-1287. 
[171] M. Medrzycki, Y. Zhang, W. Zhang, K. Cao, C. Pan, N. Lailler, J.F. McDonald, E.E. Bouhassira, Y. Fan, Histone h1.3 suppresses h19 noncoding RNA expression and cell growth of ovarian cancer cells, Cancer Res, 74 (2014) 6463-6473.

[172] V. Giambra, S. Volpi, A.V. Emelyanov, D. Pflugh, A.L. Bothwell, P. Norio, Y. Fan, Z. Ju, A.I. Skoultchi, R.R. Hardy, D. Frezza, B.K. Birshtein, Pax 5 and linker histone H1 coordinate DNA methylation and histone modifications in the 3 ' regulatory region of the immunoglobulin heavy chain locus, Mol Cell Biol, 28 (2008) 6123-6133.

[173] K. Kashiwagi, K. Nimura, K. Ura, Y. Kaneda, DNA methyltransferase 3b preferentially associates with condensed chromatin, Nucleic Acids Res, 39 (2011) 874-888.

[174] S.M. Yang, B.J. Kim, L. Norwood Toro, A.I. Skoultchi, H1 linker histone promotes epigenetic silencing by regulating both DNA methylation and histone $\mathrm{H} 3$ methylation, Proc Natl Acad Sci U S A, 110 (2013) 1708-1713.

[175] C. Martin, R. Cao, Y. Zhang, Substrate preferences of the EZH2 histone methyltransferase complex, J Biol Chem, 281 (2006) 8365-8370.

[176] R. Cao, L. Wang, H. Wang, L. Xia, H. Erdjument-Bromage, P. Tempst, R.S. Jones, Y. Zhang, Role of histone H3 lysine 27 methylation in Polycomb-group silencing, Science, 298 (2002) 1039-1043.

[177] R. Margueron, G. Li, K. Sarma, A. Blais, J. Zavadil, C.L. Woodcock, B.D. Dynlacht, D. Reinberg, Ezh1 and Ezh2 maintain repressive chromatin through different mechanisms, Mol Cell, 32 (2008) 503-518.

[178] X. Shen, Y. Liu, Y.J. Hsu, Y. Fujiwara, J. Kim, X. Mao, G.C. Yuan, S.H. Orkin, EZH1 mediates methylation on histone $\mathrm{H} 3$ lysine 27 and complements EZH2 in maintaining stem cell identity and executing pluripotency, Mol Cell, 32 (2008) 491-502.

[179] A. Vaquero, M. Scher, D. Lee, H. Erdjument-Bromage, P. Tempst, D. Reinberg, Human SirT1 interacts with histone $\mathrm{H} 1$ and promotes formation of facultative heterochromatin, Mol Cell, 16 (2004) 93-105.

[180] J.Y. Li, M. Patterson, H.K. Mikkola, W.E. Lowry, S.K. Kurdistani, Dynamic distribution of linker histone H1.5 in cellular differentiation, PLoS Genet, 8 (2012) e1002879.

[181] A. Izzo, K. Kamieniarz-Gdula, F. Ramirez, N. Noureen, J. Kind, T. Manke, B. van Steensel, R. Schneider, The genomic landscape of the somatic linker histone subtypes H1.1 to H1.5 in human cells, Cell reports, 3 (2013) 2142-2154.

[182] L. Millan-Arino, A.B. Islam, A. Izquierdo-Bouldstridge, R. Mayor, J.M. Terme, N. Luque, M. Sancho, N. Lopez-Bigas, A. Jordan, Mapping of six somatic linker histone H1 variants in human breast cancer cells uncovers specific features of H1.2, Nucleic Acids Res, 42 (2014) 4474-4493.

[183] S.L. Mackey-Cushman, J. Gao, D.A. Holmes, J.I. Nunoya, R. Wang, D. Unutmaz, L. Su, FoxP3 interacts with linker histone H1.5 to modulate gene expression and program Treg cell activity, Genes and immunity, 12 (2011) 559-567.

[184] M. El Gazzar, B.K. Yoza, X. Chen, B.A. Garcia, N.L. Young, C.E. McCall, Chromatinspecific remodeling by HMGB1 and linker histone $\mathrm{H} 1$ silences proinflammatory genes during endotoxin tolerance, Mol Cell Biol, 29 (2009) 1959-1971.

[185] T. Thorslund, A. Ripplinger, S. Hoffmann, T. Wild, M. Uckelmann, B. Villumsen, T. Narita, T.K. Sixma, C. Choudhary, S. Bekker-Jensen, N. Mailand, Histone H1 couples initiation and amplification of ubiquitin signalling after DNA damage, Nature, (2015). 
[186] H. Hashimoto, E. Sonoda, Y. Takami, H. Kimura, T. Nakayama, M. Tachibana, S. Takeda, Y. Shinkai, Histone H1 variant, H1R is involved in DNA damage response, DNA Repair (Amst), 6 (2007) 1584-1595.

[187] B. Rosidi, M. Wang, W. Wu, A. Sharma, H. Wang, G. Iliakis, Histone H1 functions as a stimulatory factor in backup pathways of NHEJ, Nucleic Acids Res, 36 (2008) 1610-1623.

[188] T. Sjoblom, S. Jones, L.D. Wood, D.W. Parsons, J. Lin, T.D. Barber, D. Mandelker, R.J. Leary, J. Ptak, N. Silliman, S. Szabo, P. Buckhaults, C. Farrell, P. Meeh, S.D. Markowitz, J. Willis, D. Dawson, J.K. Willson, A.F. Gazdar, J. Hartigan, L. Wu, C. Liu, G. Parmigiani, B.H. Park, K.E. Bachman, N. Papadopoulos, B. Vogelstein, K.W. Kinzler, V.E. Velculescu, The consensus coding sequences of human breast and colorectal cancers, Science, 314 (2006) 268274.

[189] L.D. Wood, D.W. Parsons, S. Jones, J. Lin, T. Sjoblom, R.J. Leary, D. Shen, S.M. Boca, T. Barber, J. Ptak, N. Silliman, S. Szabo, Z. Dezso, V. Ustyanksky, T. Nikolskaya, Y. Nikolsky, R. Karchin, P.A. Wilson, J.S. Kaminker, Z. Zhang, R. Croshaw, J. Willis, D. Dawson, M. Shipitsin, J.K. Willson, S. Sukumar, K. Polyak, B.H. Park, C.L. Pethiyagoda, P.V. Pant, D.G. Ballinger, A.B. Sparks, J. Hartigan, D.R. Smith, E. Suh, N. Papadopoulos, P. Buckhaults, S.D. Markowitz, G. Parmigiani, K.W. Kinzler, V.E. Velculescu, B. Vogelstein, The genomic landscapes of human breast and colorectal cancers, Science, 318 (2007) 1108-1113.

[190] H. Li, M.S. Kaminski, Y. Li, M. Yildiz, P. Ouillette, S. Jones, H. Fox, K. Jacobi, K. SaiyaCork, D. Bixby, D. Lebovic, D. Roulston, K. Shedden, M. Sabel, L. Marentette, V. Cimmino, A.E. Chang, S.N. Malek, Mutations in linker histone genes HIST1H1 B, C, D, and E; OCT2 (POU2F2); IRF8; and ARID1A underlying the pathogenesis of follicular lymphoma, Blood, 123 (2014) 1487-1498.

[191] J. Okosun, C. Bodor, J. Wang, S. Araf, C.Y. Yang, C. Pan, S. Boller, D. Cittaro, M. Bozek, S. Iqbal, J. Matthews, D. Wrench, J. Marzec, K. Tawana, N. Popov, C. O'Riain, D. O'Shea, E. Carlotti, A. Davies, C.H. Lawrie, A. Matolcsy, M. Calaminici, A. Norton, R.J. Byers, C. Mein, E. Stupka, T.A. Lister, G. Lenz, S. Montoto, J.G. Gribben, Y. Fan, R. Grosschedl, C. Chelala, J. Fitzgibbon, Integrated genomic analysis identifies recurrent mutations and evolution patterns driving the initiation and progression of follicular lymphoma, Nat Genet, 46 (2014) 176-181.

[192] M. Medrzycki, Y. Zhang, K. Cao, Y. Fan, Expression analysis of mammalian linkerhistone subtypes, Journal of visualized experiments : JoVE, (2012).

[193] D. Thierry-Mieg, J. Thierry-Mieg, AceView: a comprehensive cDNA-supported gene and transcripts annotation, Genome Biol, 7 Suppl 1 (2006) S12 11-14.

[194] B. Drabent, E. Kardalinou, D. Doenecke, Structure and expression of the human gene encoding testicular H1 histone (H1t), Gene, 103 (1991) 263-268.

[195] S. Panyim, R. Chalkley, A new histone found only in mammalian tissues with little cell division, Biochem Biophys Res Commun, 37 (1969) 1042-1049.

[196] S.M. Seyedin, W.S. Kistler, Isolation and characterization of rat testis H1t. An H1 histone variant associated with spermatogenesis, J Biol Chem, 255 (1980) 5949-5954.

[197] M.A. Lea, Relationship of $\mathrm{H} 1(0)$ histone to differentiation and cancer, Cancer biochemistry biophysics, 9 (1987) 199-209.

[198] R.R. Tonjes, D. Paul, D. Doenecke, Transgenic mice transcribing the human H1 zero histone gene exhibit a normal phenotype, Eur J Biochem, 245 (1997) 97-102.

[199] M. Murga, I. Jaco, Y. Fan, R. Soria, B. Martinez-Pastor, M. Cuadrado, S.M. Yang, M.A. Blasco, A.I. Skoultchi, O. Fernandez-Capetillo, Global chromatin compaction limits the strength of the DNA damage response, J Cell Biol, 178 (2007) 1101-1108. 


\section{Figure Legends}

Fig. 1. Multiple alignment of mouse and human somatic H1 variants. Genbank accession numbers of the protein sequences are listed in Table 1. The black line on top of amino acid sequences marks the globular domain. The conserved and the similar residues are highlighted in black and grey colors, respectively.

Fig. 2. The expression patterns of histone H1 variants during mouse development. Currently available data of indicated developmental stages in embryogenesis and postnatal tissues are shown. From zygotes to four-cell stage embryos, “++”, “+” and "-" represent relative "high expression", "low expression" and "no expression detected", respectively, of the temporal expression change of each $\mathrm{H} 1$ variant, not intended for comparisons among different H1 variants. N/D: expression not determined. Data derived from refs. [24, 93, 100-102, 104]. RNA levels were measured by semi-quantitative RT-PCR, and protein levels were measured by Western blotting or immunofluorescence microscopy. The oocyte-specific H1oo is also enriched in zygotes but gradually decreased until complete disappearance at the four-cell stage [24, 93]. The maternal $\mathrm{H}^{0}{ }^{0}$ mRNA and protein are readily detected at the zygotic stage but are degraded and replaced by zygotic $\mathrm{H}^{0}$ counterparts at the late two-cell stage [100-102]. Synthesis of H1a-e from the maternal mRNA transcripts starts at the late one-cell stage, resulting in appearance of H1a-e proteins in two-cell stage embryos [104]. The maternal mRNAs of H1a-e are degraded in late two-cell embryos concomitant with the accumulation of their zygotic transcripts [101]. Individual H1 variant- and the total H1-to-nucleosome ratios of midgestation embryos and postnatal tissues were adapted from refs. [13, 109, 117, 135]. No expression data in mice is available for H1x. As H1d and H1e are co-eluted in HPLC analysis, they were quantified together in embryos and certain tissue samples. 
Fig. 3. The expression patterns of histone H1 variants during gametogenesis. During spermatogenesis, male germ cells undergo unique chromatin remodeling. Somatic H1s were detected in spermatogonia, predominated by H1a and H1c, whose levels steadily decrease in meiotic spermatocytes until their disappearance in round spermatids $[126,133]$. H1t is expressed in pachytene spermatocytes and persists until round spermatids [127-130]. The expression of H1T2 and HILS1 is confined to spermatids, with H1T2 in the nuclei of early spermatids and HILS1 in both early and elongated spermatids [26-29]. Similar to spermatogonia, oogonia express a complement of somatic H1s. During oogenesis, somatic H1s are gradually replaced by the oocyte-specific $\mathrm{H} 1$ oo $[24,101]$. However, $\mathrm{H}^{0}$ is retained throughout oogenesis [100-102]. 
Table 1. Mammalian histone $\mathrm{H} 1$ variants $^{\mathrm{a}}$

\begin{tabular}{|c|c|c|c|c|c|c|c|c|c|c|}
\hline \multirow{2}{*}{$\begin{array}{c}\text { Histone H1 } \\
\text { variants (Alt. } \\
\text { symbols) }\end{array}$} & \multicolumn{3}{|c|}{ Mouse histone $\mathrm{H} 1$ genes } & \multicolumn{3}{|c|}{ Human histone $\mathrm{H} 1$ genes } & \multirow{2}{*}{$\begin{array}{c}\text { Gene } \\
\text { Intronic }^{b}\end{array}$} & \multirow{2}{*}{$\begin{array}{l}\text { Expression } \\
\text { Cell types }^{\mathrm{e}}\end{array}$} & \multirow{2}{*}{$\begin{array}{l}\text { Expression } \\
\text { Dependence } \\
\text { on DNA } \\
\text { replication }\end{array}$} & \multirow{2}{*}{$\begin{array}{l}\text { mRNA } \\
\text { 3'UTR }\end{array}$} \\
\hline & $\begin{array}{l}\text { Gene } \\
\text { name }\end{array}$ & $\begin{array}{c}\text { Accession } \\
\text { no. }\end{array}$ & $\begin{array}{c}\mathrm{Chr} \\
\text { location }\end{array}$ & $\begin{array}{l}\text { Gene } \\
\text { name }\end{array}$ & $\begin{array}{c}\text { Accession } \\
\text { no. }\end{array}$ & $\begin{array}{c}\mathrm{Chr} \\
\text { location }\end{array}$ & & & & \\
\hline H1a (H1.1) & Histlhla & NM_030609 & 13 & HISTIHIA & NM_005325 & 6 & No & Somatic & Yes & Stem-loop \\
\hline $\mathrm{H} 1 \mathrm{~b}(\mathrm{H} 1.5)$ & Hist 1 hlb & NM_020034 & 13 & HISTIHIB & NM_005322 & 6 & No & Somatic & Yes & Stem-loop \\
\hline $\mathrm{H} 1 \mathrm{c}(\mathrm{H} 1.2)$ & Histlhlc & NM_015786 & 13 & HISTIHIC & NM_005319 & 6 & No & Somatic & Both $^{g}$ & Both $^{\mathrm{g}}$ \\
\hline H1d (H1.3) & Histlhld & NM_145713 & 13 & HISTIHID & NM_005320 & 6 & No & Somatic & Yes & Stem-loop \\
\hline H1e (H1.4) & Histlhle & NM_015787 & 13 & HISTIHIE & NM_005321 & 6 & No & Somatic & Yes & Stem-loop \\
\hline $\begin{array}{l}\mathrm{H} 1^{0}(\mathrm{H} 1.0, \\
\mathrm{H} 1 \mathrm{fO})\end{array}$ & HIfo & NM_008197 & 15 & HIFO & NM_005318 & 22 & No & $\begin{array}{l}\text { Somatic } \\
\text { oocyte }\end{array}$ & No & Poly-A \\
\hline $\begin{array}{l}\text { H1x (H1.x, } \\
\text { H1fx) }\end{array}$ & $H 1 f x$ & NM_198622 & 6 & $H 1 F X$ & NM_006026 & 3 & $\mathrm{Y} / \mathrm{N}^{\mathrm{c}}$ & Somatic & No & Poly-A \\
\hline H1oo (H1 foo) & Hlfoo & NM_138311 & 6 & HIFOO & NM_153833 & 3 & Yes & $\begin{array}{l}\text { Oocytes, } \\
\text { zygote and 2- } \\
\text { cell embryo }\end{array}$ & No & Poly-A \\
\hline $\mathrm{H} 1 \mathrm{t}$ & Histlh1t & NM_010377 & 13 & HISTIHIT & NM_005323 & 6 & No & $\begin{array}{l}\text { Spermatocytes } \\
\text { spermatids }\end{array}$ & Yes & Stem-loop \\
\hline H1T2 & Hlfnt & NM_027304 & 15 & HIFNT & NM_181788 & 12 & No & Spermatids & No & Poly-A \\
\hline HILS1 & Hils1 & NM_018792 & 11 & HILSI & AY286318 & 17 & $\mathrm{Y} / \mathrm{N}^{\mathrm{d}}$ & Spermatids & No & Poly-A \\
\hline $\begin{array}{l}{ }^{\mathrm{c}} \text { Human H1FX } \\
{ }^{\mathrm{d}} \text { Human HILS1 } \\
{ }^{\mathrm{e}} \text { Expression dat } \\
{ }^{\mathrm{f}} \mathrm{H} 1^{0} \text { is enriched }\end{array}$ & $\begin{array}{l}\text { ta derived } f \\
\text { in differer }\end{array}$ & $\begin{array}{l}\text { des multiple tro } \\
\text { ists of two exo } \\
\text { from refs. [14, } \\
\text { ntiated cells (se }\end{array}$ & 22, 24-2 & 39, 45, 46, & $\begin{array}{l}\text { 3, 194-197]; } \\
\text { tron and mous }\end{array}$ & $\begin{array}{l}5,194] \text {; } \\
\text { (see refs } \\
\text { Hils } 1 \text { ge }\end{array}$ & $\begin{array}{l}{[55,193} \\
\text { ne is intr }\end{array}$ & ss (ref. [27]); & . & \\
\hline
\end{tabular}


Table 2. Sequence similarity among $\mathrm{H} 1$ variants in mouse and human ${ }^{\mathrm{a}}$

\begin{tabular}{|c|c|c|c|c|c|c|c|c|c|c|c|c|}
\hline & $\mathrm{mH} 1 \mathrm{a}$ & $\mathrm{mH} 1 \mathrm{~b}$ & $\mathrm{mH} 1 \mathrm{c}$ & mH1d & mH1e & $\mathrm{mH} 1^{0}$ & $\mathrm{mH} 1 \mathrm{x}$ & mH1t & mH1T2 & mHILS1 & mH1oo & \\
\hline hH1a & 78.3 & 66.2 & 64.3 & 67.7 & 66.2 & 41.0 & 30.4 & 51.8 & 13.0 & 21.6 & 17.9 & mH1a \\
\hline $\mathrm{hH} 1 \mathrm{~b}$ & 66.4 & 90.7 & 74.0 & 81.7 & 79.2 & 41.8 & 31.2 & 52.8 & 15.0 & 21.2 & 22.3 & $\mathrm{mH} 1 \mathrm{~b}$ \\
\hline hH1c & 67.7 & 76.5 & 88.3 & 81.0 & 82.3 & 39.3 & 32.2 & 50.9 & 14.5 & 20.5 & 20.2 & $\mathrm{mH} 1 \mathrm{c}$ \\
\hline hH1d & 67.7 & 77.8 & 81.1 & 87.8 & 86.4 & 40.8 & 32.5 & 54.7 & 15.1 & 19.5 & 23.1 & mH1d \\
\hline hH1e & 70.7 & 83.8 & 84.5 & 86.0 & 94.1 & 41.9 & 32.1 & 51.8 & 15.0 & 21.1 & 23.1 & mH1e \\
\hline hH1.0 & 42.6 & 43.2 & 43.4 & 38.0 & 41.9 & 94.8 & 27.2 & 33.8 & 10.3 & 15.4 & 21.4 & $\mathrm{mH} 1^{0}$ \\
\hline hH1.x & 36.4 & 32.0 & 33.8 & 32.3 & 34.1 & 29.7 & 70.9 & 26.2 & 10.0 & 16.4 & 16.5 & $\mathrm{mH} 1 \mathrm{x}$ \\
\hline hH1t & 52.1 & 49.6 & 52.2 & 48.2 & 52.0 & 29.7 & 24.2 & 61.0 & 13.4 & 24.7 & 21.5 & mH1t \\
\hline hH1T2 & 26.8 & 22.3 & 25.9 & 23.5 & 20.7 & 16.7 & 24.7 & 20.8 & 31.7 & 10.7 & 17.9 & mH1T2 \\
\hline hHILS1 & 17.1 & 16.2 & 15.6 & 16.2 & 14.7 & 8.7 & 12.1 & 18.0 & 14.9 & 28.5 & 14.1 & mHILS1 \\
\hline \multirow[t]{2}{*}{ hH1 oo } & 20.1 & 26.4 & 21.9 & 23.7 & 22.4 & 19.2 & 20.1 & 18.6 & 22.1 & 10.9 & 43.1 & mH1oo \\
\hline & hH1a & $\mathrm{hH} 1 \mathrm{~b}$ & $\mathrm{hH} 1 \mathrm{c}$ & hH1d & hH1e & hH1.0 & hH1.x & hH1t & hH1T2 & hHILS1 & hH1oo & \\
\hline
\end{tabular}

${ }^{\mathrm{a}}$ The numbers indicate the percentage of identity between two aligned $\mathrm{H} 1$ variants. Sequence comparisons between mouse H1 variants are shown in the upper half of the table (non-shaded) and those between human H1 variants are shown in the lower half (shaded). The bold numbers at the diagonal represent the sequence similarity between mouse $\mathrm{H} 1$ variants and their human counterparts. 
Table 3. Summary of properties of mice and ESCs with altered H1 expression

\begin{tabular}{|c|c|c|c|c|}
\hline \multicolumn{2}{|c|}{ H1 manipulation ${ }^{a}$} & \multirow{2}{*}{$\begin{array}{r}\text { H1/nucleosome ratio } \\
\\
\text { In mice }\end{array}$} & \multirow{2}{*}{ Phenotype } & \multirow[t]{2}{*}{ References } \\
\hline & & & & \\
\hline $\mathrm{H} 1 \mathrm{OE}$ & $\mathrm{H} 1^{0}$ & $\mathrm{~N} / \mathrm{D}$ & $\begin{array}{l}\text { Normal }\left(10-20 \text { fold increase in } \mathrm{H} 1^{0} \mathrm{mRNA}, \mathrm{N} / \mathrm{C} \text { in }\right. \\
\mathrm{H} 1^{0} \text { protein) }\end{array}$ & [198] \\
\hline \multirow[t]{9}{*}{ Single H1 KOs } & $\mathrm{H} 1^{0-/-}$ & N/C (adult liver: 0.68) & $\begin{array}{l}\text { Normal } \\
\text { Decreased dendritic cell production; reduced } \\
\text { response to vaccination with antigens }\end{array}$ & $\begin{array}{l}{[103]} \\
{[118]}\end{array}$ \\
\hline & $\mathrm{H}_{1} \mathrm{a}^{-/-}$ & $\mathrm{N} / \mathrm{C}$ (male germ cells: 0.73 ) & Normal & {$[107,135]$} \\
\hline & $\mathrm{H} 1 \mathrm{c}^{-/-}$ & $\mathrm{N} / \mathrm{C}$ & $\begin{array}{l}\text { Normal } \\
\text { Increased resistance to } \mathrm{x} \text {-ray induced apoptosis in } \\
\text { thymocytes and intestine }\end{array}$ & $\begin{array}{l}{[108]} \\
{[120]}\end{array}$ \\
\hline & & $\begin{array}{l}\text { RD (PN56 retina: WT 1.25/KO } \\
0.99)\end{array}$ & Normal retina & {$[117]$} \\
\hline & $\mathrm{H}_{1} \mathrm{~d}^{-/-}$ & $\mathrm{N} / \mathrm{C}$ & Normal & {$[108]$} \\
\hline & $\mathrm{H} 1 \mathrm{e}^{-/-}$ & $\mathrm{N} / \mathrm{C}$ & Normal & {$[108]$} \\
\hline & $\mathrm{H} 1 \mathrm{oo}^{-/-}$ & $\mathrm{N} / \mathrm{D}$ & $\begin{array}{l}\text { Normal } \\
\text { Or homeostasis }\end{array}$ & $\begin{array}{l}{[98]} \\
{[99]}\end{array}$ \\
\hline & $\mathrm{H} 1 \mathrm{t}^{-/-}$ & $\mathrm{N} / \mathrm{C}$ (male germ cells: 0.68 ) & Normal & [132-134] \\
\hline & $\mathrm{H} 1 \mathrm{~T}^{-/-}$ & $\mathrm{N} / \mathrm{D}$ & Abnormal sperms and male infertility & {$[28]$} \\
\hline \multirow[t]{5}{*}{ Double H1 KOs } & $\mathrm{H} 1^{0-/} \mathrm{H} 1 \mathrm{c}^{-/-}$ & N/C (adult liver: 0.71 ) & Normal & [108] \\
\hline & $\mathrm{H} 1^{0-/} \mathrm{H} 1 \mathrm{~d}^{-/-}$ & $\mathrm{N} / \mathrm{C}$ (adult liver: 0.71 ) & Normal & {$[108]$} \\
\hline & $\mathrm{H} 1^{0-/} \mathrm{H} 1 \mathrm{e}^{-/-}$ & N/C (adult liver: 0.76) & Normal & {$[108]$} \\
\hline & $\mathrm{H} 1 \mathrm{c}^{-/-} \mathrm{H} 1 \mathrm{e}^{-/-}$ & $\begin{array}{l}\text { N/C (adult liver: } 0.72 \text { ) } \\
\mathrm{RD} \text { (retina) }\end{array}$ & $\begin{array}{l}\text { Mild growth retardation } \\
\text { Abnormal rod photoreceptor packing }\end{array}$ & $\begin{array}{l}{[13]} \\
{[117]}\end{array}$ \\
\hline & $\mathrm{H} 1 \mathrm{a}^{-/} \mathrm{H} 1 \mathrm{t}^{-/-}$ & $\begin{array}{l}\text { RD (male germ cells: WT } \\
0.78 / \mathrm{KO} 0.59 \text { ) }\end{array}$ & Normal & {$[135]$} \\
\hline \multirow[t]{2}{*}{ Triple H1 KOs } & $\mathrm{H} 1 \mathrm{c}^{-/-} \mathrm{H} 1 \mathrm{e}^{-/-} \mathrm{H} 1^{0-/-}$ & $\begin{array}{l}\text { RD (adult liver: WT } 0.79 / \mathrm{KO} \\
0.64 \text { ) } \\
\text { RD (retina) }\end{array}$ & $\begin{array}{l}\text { Growth retardation; lower birth rate; small thymus } \\
\text { Abnormal rod photoreceptor packing }\end{array}$ & $\begin{array}{l}{[13]} \\
{[117]}\end{array}$ \\
\hline & $\mathrm{H} 1 \mathrm{c}^{-/-} \mathrm{H} 1 \mathrm{~d}^{-/ /} \mathrm{H} 1 \mathrm{e}^{-/-}$ & $\begin{array}{l}\text { RD (midgestation embryo: WT } \\
0.74 / \mathrm{KO} 0.40 \text { ) }\end{array}$ & Embryonic lethality by E11.5 & {$[13]$} \\
\hline \multirow{3}{*}{$\begin{array}{l}\text { Other compound } \\
\text { H1 KOs with } \\
\text { multiple H1 null } \\
\text { alleles }\end{array}$} & $\mathrm{H} 1 \mathrm{c}^{-/-} \mathrm{H} 1 \mathrm{~d}^{+/} \mathrm{H}_{1} \mathrm{e}^{-/-}$ & RD (thymus:WT0.83/KO 0.41) & Low birth rate; severe growth retardation & [13] \\
\hline & $\mathrm{H} 1 \mathrm{c}^{-/-} \mathrm{H} 1 \mathrm{~d}^{+/} \mathrm{H}_{1} \mathrm{e}^{-/-} \mathrm{H} 1^{0-/-}$ & N/D & Low birth rate; neonatal lethality & {$[13]$} \\
\hline & $\mathrm{H} 1 \mathrm{c}^{-/-} \mathrm{H} 1 \mathrm{~d}^{-/ /} \mathrm{H} 1 \mathrm{e}^{-/-} \mathrm{H} 1^{0-/-}$ & $\mathrm{N} / \mathrm{D}$ & Embryonic lethality & {$[13]$} \\
\hline \multicolumn{5}{|c|}{ In ESCs } \\
\hline \multirow{4}{*}{$\begin{array}{l}\text { Single } \mathrm{H} 1 \mathrm{KOs} \\
\text { (mouse) }\end{array}$} & $\mathrm{H} 1^{0-/}$ & $\mathrm{N} / \mathrm{D}$ & Normal ESC differentiation & \# \\
\hline & $\mathrm{H} 1 \mathrm{c}^{-/-}$ & RD (WT $0.45 / \mathrm{KO} 0.38$ ) & Normal cell morphology and proliferation; normal & [154] \\
\hline & $\mathrm{H}_{1} \mathrm{~d}^{-/-}$ & RD (WT 0.45/KO 0.35) & $\begin{array}{l}\text { ESC differentiation and teratoma formation; specific } \\
\text { expression changes of Hox genes }\end{array}$ & [154] \\
\hline & $\mathrm{H} 1 \mathrm{e}^{-/-}$ & RD (WT 0.45/KO 0.35) & & {$[154]$} \\
\hline $\begin{array}{l}\text { Triple } \mathrm{H} 1 \mathrm{KO} \\
\text { (mouse) }\end{array}$ & $\mathrm{H}^{-1--} \mathrm{H}^{-1 /-} \mathrm{H} 1 \mathrm{e}^{-/-}$ & RD (ESCs: WT 0.46/KO 0.25) & $\begin{array}{l}\text { Reduced chromatin compaction; specific changes in } \\
\text { gene expression and DNA methylation } \\
\text { Chromocenter clustering and de-repression of major } \\
\text { satellite repeats } \\
\text { Enhanced DNA damage response } \\
\text { Decreased chromatin flexibility in gene rich TAD } \\
\text { ESCs more resistant to spontaneous differentiation; } \\
\text { impaired EB and neural differentiation } \\
\text { Dysregulated in specification of mesendoderm and } \\
\text { neuroectoderm }\end{array}$ & $\begin{array}{l}{[153]} \\
{[109]} \\
{[199]} \\
{[163]} \\
{[16]} \\
{[16]} \\
{[105]}\end{array}$ \\
\hline H1 KD (human) & $\mathrm{H} 1^{0}$ & $\mathrm{~N} / \mathrm{D}$ & $\begin{array}{l}\text { Lack of induction of a few differentiation associated } \\
\text { genes }\end{array}$ & {$[106]$} \\
\hline
\end{tabular}

${ }^{\mathrm{a}} \mathrm{OE}$, overexpression; KO, knockout; $\mathrm{KD}$, knockdown.

${ }^{\mathrm{b}} \mathrm{N} / \mathrm{C}$, no change; RD, reduced; N/D, not determined; WT, wildtype.

\# Pan, Zhang, Fan unpublished observation. 


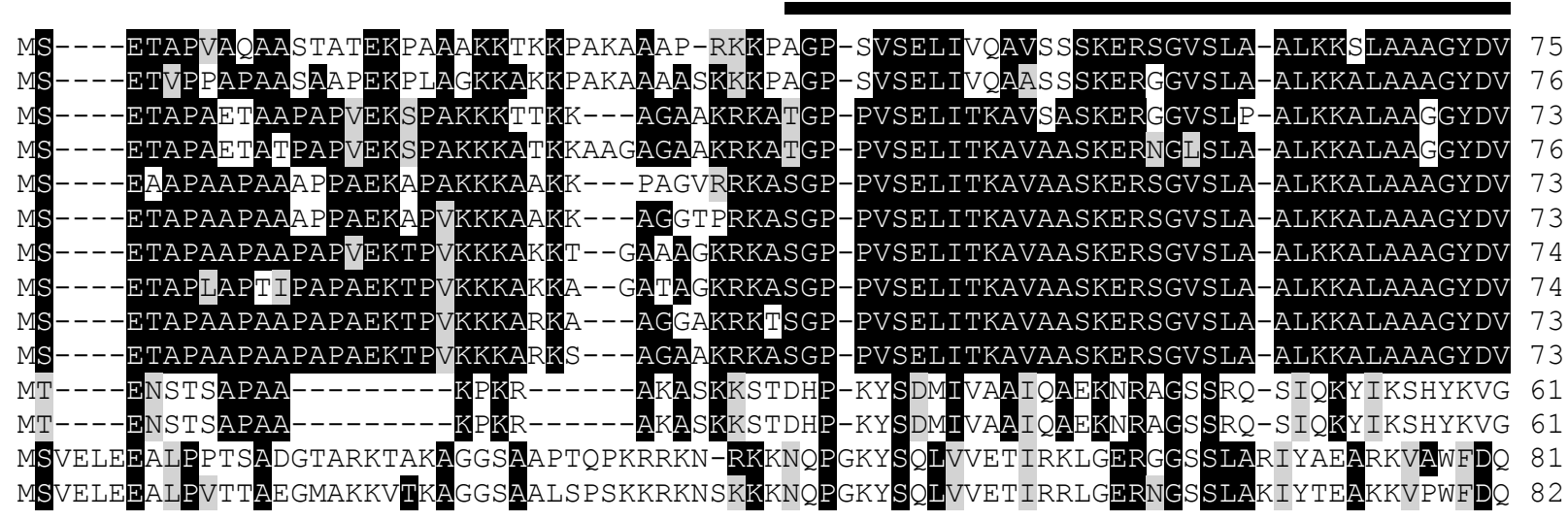

mH1a

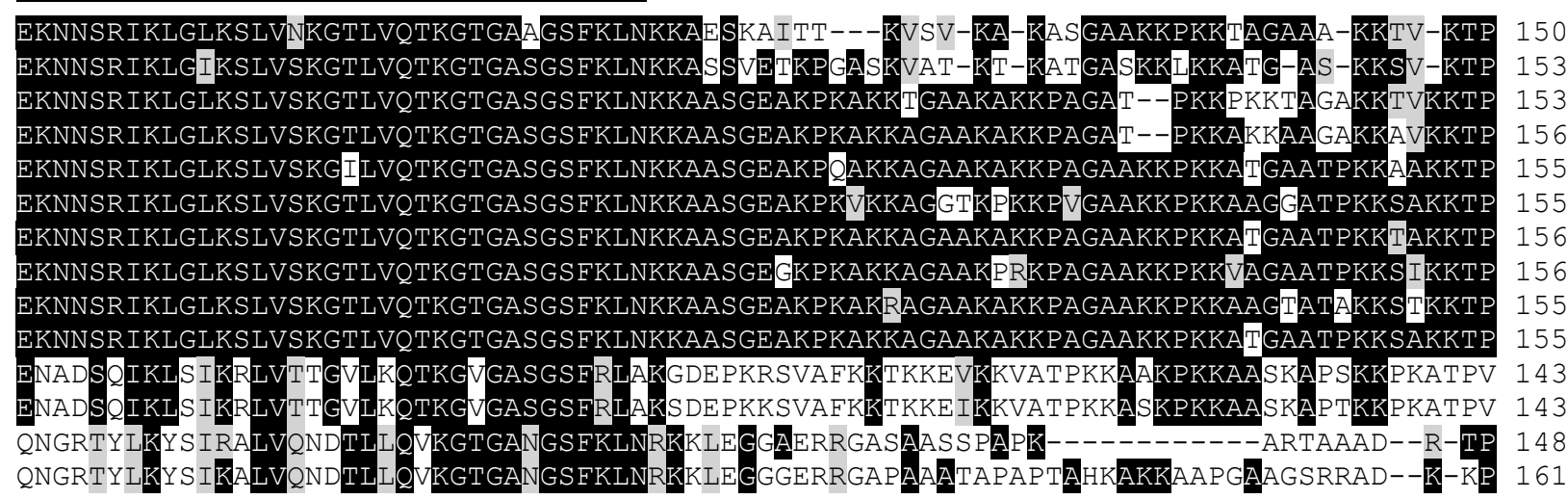

mH1a

hHla

mH1b

hH1b

mH1c

hH1c

mH1d

hH1d

mHle

hH1e

$\mathrm{mH} 10$

hH1. 0

$\mathrm{mH} 1 \mathrm{x}$

hH1. $x$

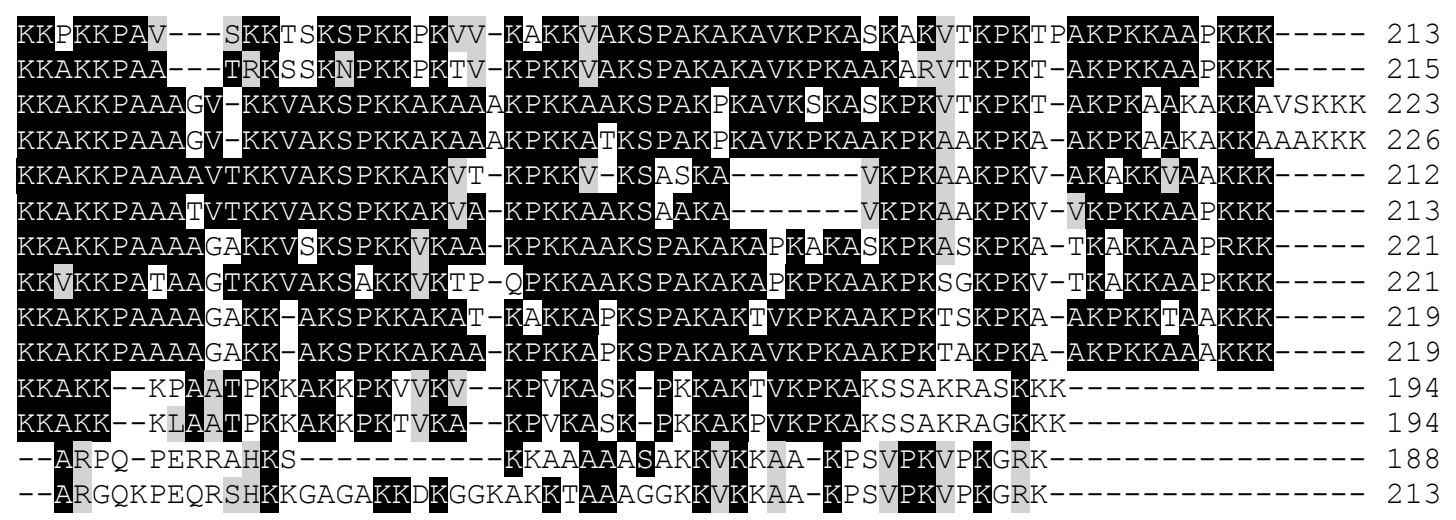




\begin{tabular}{|c|c|c|c|c|c|c|c|c|c|c|c|c|c|c|}
\hline & \multicolumn{2}{|c|}{ Zygote } & \multicolumn{2}{|c|}{ 2-Cell } & \multicolumn{2}{|c|}{ 4-Cell } & \multirow[t]{3}{*}{ Midgestation } & \multicolumn{7}{|c|}{ Tissues } \\
\hline & & & & & & & & \multicolumn{2}{|c|}{ Liver } & \multicolumn{2}{|c|}{ Retina } & \multirow[t]{2}{*}{ Thymus } & \multirow[t]{2}{*}{ Spleen } & \multirow{2}{*}{$\begin{array}{l}\text { Male germ } \\
\text { cells }\end{array}$} \\
\hline & & & & & & & & $\overline{\text { (Neonatal) }}$ & (Adult) & (PN1) & (PN56) & & & \\
\hline & RNA & Protein & RNA & Protein & RNA & Protein & $\begin{array}{c}\text { Protein } \\
\text { (H1/nucl ratio) }\end{array}$ & \multicolumn{7}{|c|}{ Protein ( $\mathrm{H} 1 /$ nucl ratio) } \\
\hline $\mathrm{H} 100$ & ++ & ++ & + & + & - & - & - & - & - & - & - & - & - & - \\
\hline $\mathrm{H} 1{ }^{0}$ & ++ & ++ & + & + & - & + & 0.02 & 0.07 & 0.23 & 0.06 & 0.11 & 0.02 & 0.03 & 0.02 \\
\hline $\mathrm{H} 1 \mathrm{a}$ & ++ & - & ++ & + & ++ & ++ & 0.11 & 0.05 & 0.01 & 0.13 & 0.11 & 0.09 & 0.05 & 0.27 \\
\hline $\mathrm{H} 1 \mathrm{~b}$ & ++ & - & + & + & ++ & ++ & 0.15 & 0.11 & 0.12 & 0.2 & 0.11 & 0.14 & 0.10 & 0.01 \\
\hline $\mathrm{H} 1 \mathrm{C}$ & ++ & - & + & + & ++ & ++ & 0.12 & 0.16 & 0.10 & 0.21 & 0.37 & 0.22 & 0.30 & 0.13 \\
\hline $\mathrm{H} 1 \mathrm{~d}$ & ++ & - & + & + & ++ & ++ & 0.34 & 0.23 & 0.11 & 0.42 & 0.55 & 0.29 & 0.23 & 0.09 \\
\hline $\mathrm{H} 1 \mathrm{e}$ & ++ & - & + & + & ++ & ++ & $(\mathrm{H} 1 \mathrm{~d} / \mathrm{e})$ & 0.14 & 0.32 & $(\mathrm{H} 1 \mathrm{~d} / \mathrm{e})$ & $(\mathrm{H} 1 \mathrm{~d} / \mathrm{e})$ & 0.08 & 0.18 & $(\mathrm{H} 1 \mathrm{~d} / \mathrm{e})$ \\
\hline $\mathrm{H} 1 \mathrm{t}$ & - & - & - & - & - & - & - & - & - & - & - & - & - & 0.23 \\
\hline Total H1 & $\mathrm{N} / \mathrm{D}$ & $\mathrm{N} / \mathrm{D}$ & $\mathrm{N} / \mathrm{D}$ & $\mathrm{N} / \mathrm{D}$ & $\mathrm{N} / \mathrm{D}$ & $\mathrm{N} / \mathrm{D}$ & 0.74 & 0.76 & 0.79 & 1.02 & 1.25 & 0.83 & 0.89 & 0.75 \\
\hline
\end{tabular}


Spermatogenesis

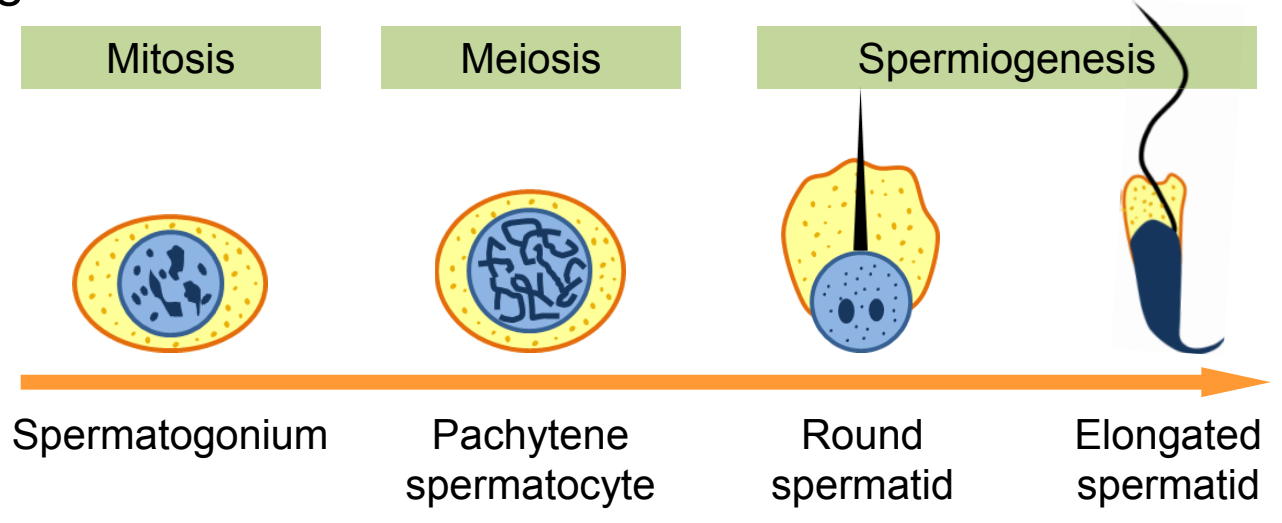

$\mathrm{H} 1 \mathrm{a}>\mathrm{H} 1 \mathrm{c}>\mathrm{H} 1 \mathrm{~b}, \mathrm{H} 1 \mathrm{~d}, \mathrm{H} 1 \mathrm{e}, \mathrm{H}{ }^{0}$

H1t

H1T2

HILS1

Oogenesis

$\begin{array}{cccc}\text { Mitosis } & \text { Meiosis I } & \text { Meiosis II } \\ \text { Oogonium } & \begin{array}{c}\text { Primary } \\ \text { oocyte }\end{array} & \begin{array}{c}\text { Secondary } \\ \text { oocyte }\end{array} & \text { Ovum } \\ \text { H10 } & & \end{array}$

H1a, H1b, H1c, H1d, H1e 